\title{
Nanoscale
}

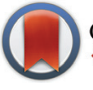

CrossMark \& click for updates

Cite this: Nanoscale, 2016, 8, 18070

\section{Carbon nanotubes stimulate synovial inflammation by inducing systemic pro-inflammatory cytokines $\uparrow$}

\author{
Juan Ma, ${ }^{a}$ Ruibin Li, ${ }^{\text {b,c }}$ Guangbo Qu, ${ }^{a}$ Huiyu Liu, ${ }^{d}$ Bing Yan, ${ }^{e}$ Tian Xia, ${ }^{b}$ Yajun Liu ${ }^{f}$ and \\ Sijin Liu*a
}

Carbon nanotubes (CNTs) have promising applications in a wide range of biomedical fields, including imaging, drug/gene delivery and other therapeutics; however, the biosafety concerns of CNTs should be addressed. To date, many reports have documented the toxicological effects on the cells, tissue or organs that are in direct contact with the tubes; however, there is limited evidence to unravel the secondary toxicity upon CNT treatment. Moreover, more effort is needed to gain a definitive understanding of the adverse outcome pathway (AOP) for CNTs, and a pragmatic framework for risk assessment has not been established yet. In the current study, we aimed to decipher the secondary toxicity to joints under CNT exposure. We demonstrated that carboxylated multi-wall CNTs (MWCNTs-COOH) significantly provoked systemic pro-inflammatory responses, leading to synovial inflammation within knee joints, as evidenced by the infiltration of pro-inflammatory cells in the synovium and meniscus. Mechanistic studies showed that MWCNTs-COOH stimulated pro-inflammatory effects by activating macrophages, and the secreted pro-inflammatory cytokines primed the synoviocytes and chondrocytes, resulting in enhanced production of a large array of enzymes involved in articular cartilage degeneration, including matrix metalloproteinase (MMP) members and cyclooxygenase (COX) members, and increased enzymatic activity of MMPs was demonstrated. Blockade of the cytokines by antibodies significantly attenuated the production of these enzymes. Our current study thus suggests that there is a novel secondary toxicity of CNTs, namely a new AOP to understand the indirect effects of carbon nanotubes: synovial inflammation Accepted 8th September 2016

DOI: $10.1039 / c 6 n r 06041 b$ due to the alteration of the priming state of synoviocytes and chondrocytes under CNT-induced systemic www.rsc.org/nanoscale inflammatory conditions

\section{Introduction}

The rapid increase in the production and use of nanomaterials results in their inevitable release into the environment, causing potential detrimental effects on human health. Thus,

\footnotetext{
${ }^{a}$ State Key Laboratory of Environmental Chemistry and Ecotoxicology, Research Center for Eco-Environmental Sciences, Chinese Academy of Sciences, Beijing 100085, China. E-mail: sjliu@rcees.ac.cn; Fax: +86 10 62849330; Tel: +861062849330

${ }^{b}$ Division of NanoMedicine, Department of Medicine, University of California, Los Angeles, California 90095, USA

${ }^{c}$ School for Radiological and Interdisciplinary Sciences (RAD-X), Collaborative Innovation Center of Radiation Medicine of Jiangsu Higher Education Institutions, Soochow University, Suzhou, 215123, China

${ }^{d}$ Beijing Key Laboratory of Bioprocess, College of Life Science and Technology, Beijing University of Chemical Technology, Beijing 100029, China

${ }^{e}$ School of Chemistry and Chemical Engineering, Shandong University, Jinan 250100, China

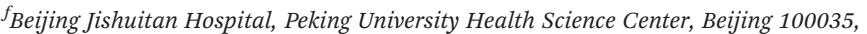
China

$\dagger$ Electronic supplementary information (ESI) available: Additional experimental results related to this work are provided online. See DOI: 10.1039/c6nr06041b
}

to understand the health impact of nanomaterials is of great importance. As a material with novel physicochemical properties, carbon nanotubes (CNTs) have been used in a large variety of industrial and commercial applications including electronics, biomedical devices and drug delivery vehicles. ${ }^{1-4}$ Meanwhile, numerous studies have documented the in vitro and in vivo toxicities of CNTs. ${ }^{5-9}$ A number of toxicological effects of CNTs have been identified including inflammation, fibrosis, genotoxicity and immunotoxicity. ${ }^{10,11}$ Despite this progress, continuous effort is warranted to gain more insights into the definitive adverse outcome pathways (AOPs) for nanomaterials with high exposure risk for human beings, and a validated framework for human health risk assessment upon CNTs has not been developed yet. AOP is a recently introduced conceptual framework that characterizes the documented and testable processes upon chemicals to link molecular perturbations and the biological responses and consequences at multiple levels. ${ }^{12,13}$

Nonetheless, most previous studies looked into the toxic effects on the directly targeted tissues/organs, providing little insight into their secondary effects beyond their primary 
targets. Only recently, limited data suggested a possible transportation of CNTs from primary exposure sites to secondary sites; however, no detailed toxicological effects were examined. $^{14,15}$ Another piece of evidence revealed that nano-sized carbon black could induce significant hepatic metabolic disorders in the offspring. ${ }^{16}$ Although inconclusive, these preliminary data pointed out the importance of investigating the secondary effects following CNT exposure.

CNT-induced pro-inflammatory effects have been established by a number of previous studies. ${ }^{11,17,18}$ Inflammation disrupts various pathways responsible for biological homeostasis and may cause detrimental health problems, such as anemia of inflammation and arthritis. ${ }^{19,20}$ Notably, inflammation is an important risk factor for the onset and progression of osteoarthritis (OA) and rheumatoid arthritis (RA). $\mathrm{OA}$ is an inflammatory disease characterized by synovial inflammation with immune cell infiltration and pro-inflammatory factor secretion. ${ }^{21,22} \mathrm{RA}$ is also a chronic inflammatory disease characterized by synovitis and associated with erosion of articular cartilage and marginal bone as well as joint destruction. ${ }^{20}$ The development of RA closely relies on the activation of immune cells and systemic pro-inflammatory responses, which fundamentally alters metabolic pathways implicated in RA pathogenesis. ${ }^{22}$ Invading pathogens or their products activate immune cells (such as macrophages and other pro-inflammatory cells), leading to the production of pro-inflammatory cytokines and consequently the widespread systemic pro-inflammatory responses, which further stimulate a gradual deterioration of tissues within joints. ${ }^{23}$ To date, limited data are available on the toxicity of nanomaterials to chondrocytes or synoviocytes. A previous study reported that gold and silver nanoparticles showed toxicity to cultured chondrocytes. $^{24}$ Since these findings are still preliminary, further studies are required to clarify the influence of nanomaterials on joints.

In view of the recent progress, we hypothesized that CNT exposure may cause secondary toxicity to joints through systemic inflammation. Therefore, we studied the effects of CNT exposure on synovial cells and chondrocytes using in vivo and in vitro models and probed the potential mechanism by which CNTs induced joint degeneration. To the best of our knowledge, no similar studies have been reported, and our findings could have a positive impact on engendering future studies.

\section{Materials and methods}

\section{Carboxylated multi-wall CNT (MWCNT-COOH) preparation and physiochemical characterization}

Pristine MWCNTs were purchased from XF Nano Inc. (China), and MWCNTs-COOH were prepared following the established instructions, as previously described. ${ }^{25,26}$ The MWCNT morphology was examined using transmission electron microscopy (TEM) (Hitachi, H7650, Japan) and scanning electron microscopy (SEM) (Hitachi, S-3000N, Japan) analyses. Length and diameter distributions were calculated based on the TEM analysis. The surface charge of MWCNT suspensions in deionized (DI) water, phosphate-buffered saline (PBS) and cell culture medium was measured with a Zeta-sizer (Malvern Nano ZS, Nalvem, UK). An ultraviolet-visible spectrophotometer (Shimadzu, UV-3600, Kyoto, Japan) was used to measure the ultraviolet-visible (UV-vis) absorption spectrum from $190 \mathrm{~nm}$ to $800 \mathrm{~nm}$ for MWCNT-COOH samples at $10 \mu \mathrm{g} \mathrm{mL}{ }^{-1}$. Fourier transform infrared spectroscopy (FTIR) was applied to recognize functional groups on the CNT surface. The FTIR spectrum was recorded from 4000 to $400 \mathrm{~cm}^{-1}$ on a FTIR instrument (Spectrum One, Perkin Elmer Instruments Co. Ltd, USA). MWCNT-COOH samples were deposited onto silicon wafers, followed by air drying and X-ray photoelectron spectroscopy (XPS) analysis, following a standard protocol. ${ }^{25}$

After microwave-mediated digestion of MWCNT samples on a MARS machine (CEM Corp., Matthews, NC), heavy metal impurities (e.g. $\mathrm{Fe}, \mathrm{Al}, \mathrm{Ag}, \mathrm{Cd}, \mathrm{Hg}, \mathrm{Pb}$ and 19 other metals) were detected by inductively coupled plasma mass spectrometry (ICP-MS) on an Agilent 7500 instrument (Agilent, Tokyo, Japan). 15 polycyclic aromatic hydrocarbons (PAHs) recommended by the Environmental Protection Agency (EPA) (including acenaphthene, acenaphthene, fluorine, phenanthrene, anthracene, fluoranthene, pyrene, benzo(a)anthracene, chrysene, benzo(b)fluoranthene, benzo(k)fluoranthene, benzoapyrene, indeno(1,2,3-cd)pyrene, dibenz( $a, h)$ anthracene and benzoperylene $)^{27,28}$ were measured using Agilent high resolution gas chromatography coupled with low resolution mass spectrometry, as previously described. ${ }^{29}$ To determine the endotoxin level, MWCNT samples were subjected to an endotoxin test using a Limulus Amebocyte Lysate (LAL) kit (Pierce, USA).

\section{Cell culture and treatment with MWCNTs}

The human macrophage cell line (THP-1), a human chondrocyte cell line (SW-1353) and a human synoviocyte cell line (SW-982) were purchased from the Shanghai Cell Bank of Type Culture Collection of the Chinese Academy of Sciences. Cells were accordingly cultured in Dulbecco's Modified Eagle's Medium (DMEM), RMPI 1640 (Hyclone) or Leibovitz's L-15 Medium (Gibco), supplemented with 10\% fetal bovine serum (FBS, Gibco) and $100 \mathrm{U} \mathrm{mL}^{-1}$ penicillin/streptomycin (Gibco), at $37{ }^{\circ} \mathrm{C}$ and with $5 \% \mathrm{CO}_{2}$. The HEK293/TLR4/MD2/CD14 cell line (namely HEK293-TLR4 cells), originally derived from InvivoGen Inc. (San Diego, CA, USA), was a gift from Dr Shitao $\mathrm{Li}^{30}$ These cells were cultured in DMEM (Sigma-Aldrich) with $10 \%$ FBS, 100 units per $\mathrm{mL}$ of penicillin $\mathrm{G}$, and $100 \mu \mathrm{g} \mathrm{mL} \mathrm{m}^{-1}$ of streptomycin. Bacterial lipopolysaccharides (LPS, at $1 \mu \mathrm{g} \mathrm{mL} \mathrm{m}^{-1}$ ) was used as a positive control here to activate HEK293-TLR4 cells. THP-1 cells were pretreated with $1 \mu \mathrm{g} \mathrm{m} \mathrm{m}^{-1}$ phorbol 12myristate 13-acetate (PMA, Promega Inc., USA) for $18 \mathrm{~h}$ prior to MWCNT exposure. MWCNTs were suspended in PBS for cell exposure at various concentrations. Untreated cells received the same volume of PBS accordingly.

In terms of inhibition of NF- $\kappa \mathrm{B}$ signaling, a NF- $\kappa \mathrm{B}$ selective inhibitor, PDTC (Sigma), at a concentration of $20 \mu \mathrm{M}$ was used 
to pre-treat THP-1 cells for $1.5 \mathrm{~h}$ prior to MWCNT exposure. Regarding the inhibition of toll-like receptor 4 (TLR4) signaling, THP-1 cells were pre-treated for $6 \mathrm{~h}$ with CLI-095 ( $1 \mu \mathrm{g} \mathrm{mL}^{-1}$; InvivoGen) to repress the signaling mediated by the intracellular domain of TLR4. To access gene expression and protein concentrations, cells were first seeded at a density of $1.0 \times 10^{6}$ per well in 6-well plates (Corning Inc., NY, USA) at $37^{\circ} \mathrm{C}$ overnight prior to CNT exposure.

\section{Cell viability assay and BrdU incorporation assay}

To determine cell viability, cells were first seeded into 96-well plates with a density of $0.8 \times 10^{4}$ per well (Corning), and then incubated at $37{ }^{\circ} \mathrm{C}$ with $5 \% \mathrm{CO}_{2}$ overnight. Afterwards, cells were treated with CNT materials for $24 \mathrm{~h}$, followed by the cell viability assay with a LIVE/DEAD Viability/Cytotoxicity Kit following the manufacturer's instructions (Invitrogen, Thermo Fisher Scientific Inc., USA).

To evaluate cell division, the BrdU incorporation assay was carried out with a kit from Roche (Roche Inc., Switzerland). Briefly, $10 \mu \mathrm{M}$ BrdU loading solution was incubated with THP-1 cells together with MWCNT exposure for $24 \mathrm{~h}$. Afterwards, cells were fixed for $30 \mathrm{~min}$, followed by removal of the mixture solution. After incubation with the anti-BrdU antibody $(\mathrm{Ab})$ for $60 \mathrm{~min}$ at room temperature, cells were incubated with a substrate solution, followed by washing 5 times with washing buffer. The immune complexes were then recognized through their substrate reaction according to the instructions provided by the manufacturer.

\section{Cellular reactive oxygen species (ROS) determination}

For ROS determination, THP-1 cells were first seeded in 96well plates overnight and then treated with MWCNTs at different concentrations for $24 \mathrm{~h}$. Afterwards, cells were washed with PBS and then incubated with dichlorofluoresceindiacetate (DCF-DA, Sigma) at $10 \mu \mathrm{M}$ for $30 \mathrm{~min}$. After incubation and total removal of the dye with PBS, DCF fluorescence was thereafter tested at $525 \mathrm{~nm}$ using an excitation wavelength of $488 \mathrm{~nm}$ on a plate reader (Thermo Fisher Scientific Inc., USA), as described previously. ${ }^{31}$

\section{qRT-PCR analysis}

Total cellular RNAs were isolated from cells using Trizol reagent following the manufacturer's instruction (Invitrogen). First-strand cDNA was synthesized by reverse transcribing total RNAs using a reverse transcription kit (Promega). Afterwards, the relative expression levels for the interested genes were assessed using a SYBR Green qPCR mix (Promega Inc.) on an Mx3005P qRT-PCR instrument (Bio-Rad Inc., California, USA), according to a standard protocol: denaturing step for $10 \mathrm{~min}$ at $95{ }^{\circ} \mathrm{C}$, followed by 45 cycles of $10 \mathrm{~s}$ at $95{ }^{\circ} \mathrm{C}, 30 \mathrm{~s}$ at $60^{\circ} \mathrm{C}$, and $20 \mathrm{~s}$ at $72{ }^{\circ} \mathrm{C}$. Fluorescence was acquired for each cycle. The primers used in the current study are provided in ESI Table $1 . \dagger$ Glyceraldehyde-3-phosphate dehydrogenase (GAPDH) was used as the loading control. The relative expression levels of the interested genes were determined using the method of $\Delta \mathrm{Ct}^{32,33}$

\section{Western blotting analysis}

Cells were first collected and then lysed in RIPA lysis buffer (Solarbio Inc., China) containing a 15\% proteinase inhibitor cocktail (Roche) after washing with cold PBS. The concentrations of total proteins were thereafter measured with the Lowry assay. The same amount of proteins $(20 \mu \mathrm{g})$ was first subjected to $10 \%$ SDS-PAGE (Bio-Rad), and proteins were then transferred onto nitrocellulose membranes. Afterwards, blotting analysis was carried out with an anti-human matrix metalloproteinase (MMP) MMP-2 antibody (Ab) (1:500, Santa Cruz Biotechnology Inc.).

For the assay of the translocation of p65 into the nucleus and the degradation of IKB $\alpha$ in THP-1 cells following MWCNT exposure, the nuclear proportion was separately collected with a nucleoprotein extraction kit (Solarbio), and the total cellular proteins were also extracted. The Abs were as follows: antihuman p65 (1:200, Bioss Inc., Beijing, China), anti-human IкB $\alpha$ ( $1: 200$, Bioss), anti-human GAPDH ( $1: 1000$, Santa Cruz) and anti-human PARP (1:200, Bioss). Poly(ADP-ribose) polymerase (PARP) was used as the internal control for the nuclear proteins. GAPDH was used as a loading control of the total cellular proteins. The intensity for the autoradiogram in Western blot bands was determined using the software ImageJ (NIH, USA, http://rsbweb.nih.gov), and the band intensity was normalized to that of the loading control.

\section{Gelatin zymography}

After treatment for $24 \mathrm{~h}$, total proteins from THP-1 cells were collected and the protein concentration was assayed. Afterwards, the activities of MMP-2 and MMP-9 were determined by gelatin zymography, as described previously. ${ }^{34}$

\section{Neutralization assay}

The supernatants prepared by gelatin zymography were used in neutralization experiments following the instructions described in our previous report. ${ }^{35}$ Briefly, the supernatants were applied to the treated synoviocyte with the addition of $10 \mu \mathrm{g} \mathrm{mL}{ }^{-1}$ anti-TNF-alpha (TNF- $\alpha$ ) Ab or anti-IL-1-beta (IL-1 $\beta$ ) $\mathrm{Ab}$ for $12 \mathrm{~h}$. In contrast, the control cells were treated with the supernatants containing normal IgG at $10 \mu \mathrm{g} \mathrm{mL}^{-1}$. These Abs were purchased from Bioss Inc.

\section{Animal experimentation}

Male BALB/c mice were purchased from the Vital River Laboratories, Beijing, China. These mice were 7 weeks old with the body weight of around $25 \mathrm{~g}$. Mice were bred under a specific pathogen-free (SPF) facility. Prior to experimentation, all animal experimental protocols were approved by the Animal Ethics Committee at the Research Center for EcoEnvironmental Sciences, Chinese Academy of Sciences. MWCNT-COOH materials were administered by intravenous (I.V.) injection at $0.5,1.0,2.0,4.0 \mathrm{mg}$ per $\mathrm{kg}$ body weight (in $100 \mu \mathrm{L}$ with 1 injection only), lasting for 2 days, or were administered at $4.0 \mathrm{mg}$ per kg body weight for $6 \mathrm{~h}, 12 \mathrm{~h}, 24 \mathrm{~h}$, 48 h, 7 days and 14 days. Sera were separated from peripheral 
blood for the assay of cytokines. Prior to taking the photos of livers and lungs, blood in organs was pumped out using a peristaltic pump (Baoding Longer Precision Pump Co., Ltd) through the hepatic portal vein with PBS containing 1\% heparin. Tissue samples were collected and fixed in 4\% PBSbuffered formaldehyde for further histological examination. Since MWCNTs were dissolved in PBS (namely the vehicle solution) for in vivo administration, untreated animals (i.e. CTRL SHAM) received PBS only.

\section{Histological analysis, immunohistochemistry and TEM analysis of tissues}

Tissue specimens were fixed in 4\% PBS-buffered formaldehyde and then embedded in paraffin, followed by sectioning and hematoxylin-eosin (H\&E) staining following a standard protocol. For knee specimens, they were decalcified in 10\% ethylene diamine tetraacetic (EDTA) at room temperature by changing to fresh decalcifying solution every four days until becoming soft before embedding and sectioning. Immunohistochemistry was performed following a standard procedure, as described previously. ${ }^{36}$ Briefly, sections were incubated with Abs against COX-2 (1:100, Goodbio Technology Co. Ltd, Wuhan) or MMP-9 (1: 100, Goodbio Technology). Immunocomplexes were visualized using 3,3'-diaminobenzidine (DAB) as a selenium organic reagent. Sections were finally counterstained with hematoxylin, and were thereafter checked under a microscope (Nikon Eclipse TI-SR, Japan). The integrated optical density (IOD) in each field was determined using the software ImageJ (NIH).

Articular cartilage flayed from long bones was fixed with a $2.5 \%$ glutaraldehyde solution and embedded with epoxy resin. Ultrathin sections (70 nm) were placed on the grids, and then stained with $1 \%$ lead citrate and $0.5 \%$ uranyl acetate. Stained samples were thereafter examined using a high-resolution JEOL JEM 2010F transmission electron microscope (Hitachi Scientific Instruments, Japan).

\section{Complete blood count (CBC) analysis}

For CBC analysis, $20 \mu \mathrm{L}$ fresh blood was diluted into $2 \mathrm{~mL}$ standard dilution buffer, and the diluted samples were subjected to the analysis on a hematology analyzer (Nihon Kohden, MEK-7222K, Japan).

\section{Flow cytometry (FACS) analysis}

For cell death analysis, cells were collected after treatment, followed by FITC-conjugated Annexin V and propidium iodide (PI) staining (BD Biosciences). Apoptotic and necrotic cells were then assessed by FACS analysis following a standard protocol provided by the manufacturer. To sort macrophages in the spleen, the total splenic cells were subjected to RBC lysis with a RBC lysis buffer. Thereafter, a PE-conjugated antimouse F4/80 Ab (BioLegend, Inc., San Diego, USA) was used to recognize monocytes/macrophages through FACS analysis. FACS analysis was done using a BD FACS Calibur ${ }^{\mathrm{TM}}$ machine (BD Biosciences) according to standard instructions.

\section{Cytokine determination}

The concentrations of cytokines in sera or culture medium were assayed with ELISA kits following the manufacturer's instructions (R\&D Systems). Briefly, $50 \mu \mathrm{L}$ serum or culture medium was added into plates provided by the manufacturer. After incubation for $2 \mathrm{~h}$ at room temperature, the plates were washed 4 times with a washing solution. Afterwards, the conjugate solution $(100 \mu \mathrm{L})$ was added, and the plates were washed 4 times after $2 \mathrm{~h}$ incubation. Finally, the absorption value was recorded on a microplate reader (Varioskan Flash, Thermo, USA). The concentrations of cytokines were calculated according to standard curves that were developed using standard solutions.

For the detection of MMP-3 secreted by SW-982 cells in response to culture medium from MWCNT-treated THP-1 cells, both THP-1 cells and SW-982 cells were cultured with serum-free medium. The supernatants of SW-982 cells were collected after $12 \mathrm{~h}$ incubation with the medium from 20 and $40 \mu \mathrm{g} \mathrm{mL} \mathrm{m}^{-1}$ MWCNT-treated THP-1 cells. The content of MMP-3 was measured with an ELISA kit according to the manufacturer's instructions (QnDSystem ${ }^{\mathrm{TM}}$, Xinqidi Biological Technology Co., Ltd, Wuhan).

\section{Statistical analysis}

The difference for the single treated group relative to the untreated control was assessed using an independent $t$-test. The significance of the mean difference for two or more treatment groups relative to the untreated control was determined by one-way ANOVA. Data are shown as the mean \pm standard error. Statistical significance was determined using $P$ values less than 0.05 .

\section{Results and discussion}

\section{Preparation and characterization of MWCNTs-COOH}

Since carboxylated CNTs are the most widely used functionalized type in biomedical applications because of their high hydrophilicity and dispersibility in an aqueous environment, ${ }^{25,37}$ we selected MWCNTs-COOH in the current study. MWCNTs-COOH were prepared from pristine MWCNTs as the starting material, as previously described. ${ }^{25,38}$ Then, the physicochemical properties of the prepared MWCNTs-COOH were thoroughly characterized. The morphology of MWCNTs$\mathrm{COOH}$ was assessed by TEM (Fig. 1A) and SEM (Fig. 1B), and the results showed typical morphological feature of CNTs, which is a curvy fiber-like structure. Further analysis of TEM data revealed that more than $70 \%$ of MWCNTs-COOH had an average length ranging from 250 to $450 \mathrm{~nm}$, with the outer diameter of around $23 \mathrm{~nm}$ and the inner diameter of around $11 \mathrm{~nm}$ (Fig. 1C). The hydrodynamic diameter of MWCNTs was around $100 \mathrm{~nm}$ in water, and increased to larger than $680 \mathrm{~nm}$ in PBS (Fig. 1D, $P<0.001$ ), presumably due to salt-induced neutralization and shrinkage of the electric double layer of CNT materials. ${ }^{39,40}$ Its hydrodynamic diameter decreased to $177 \mathrm{~nm}$ in cell culture medium supplemented with 10\% FBS 
(A)

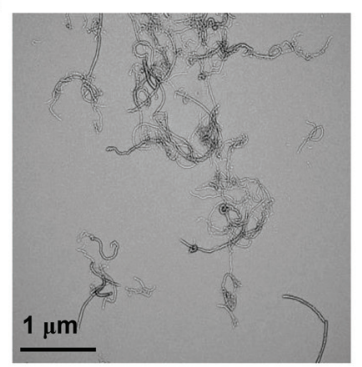

(C)

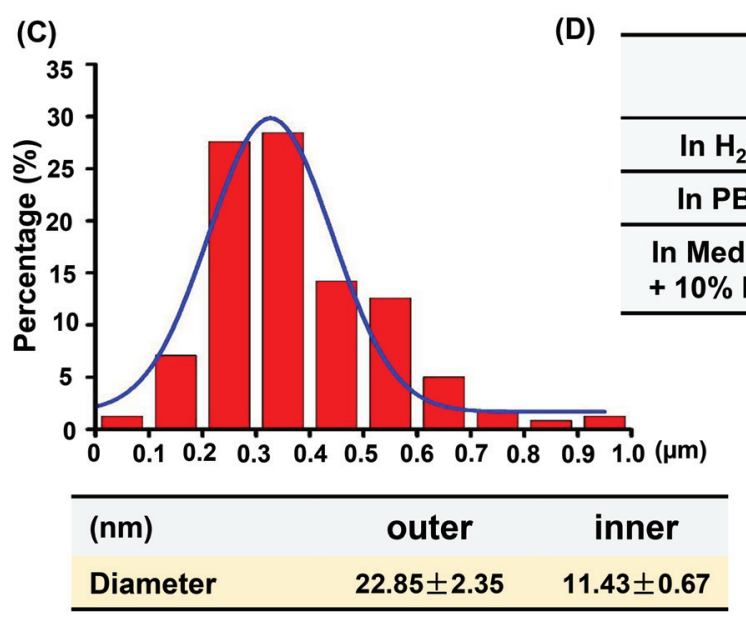

(F)

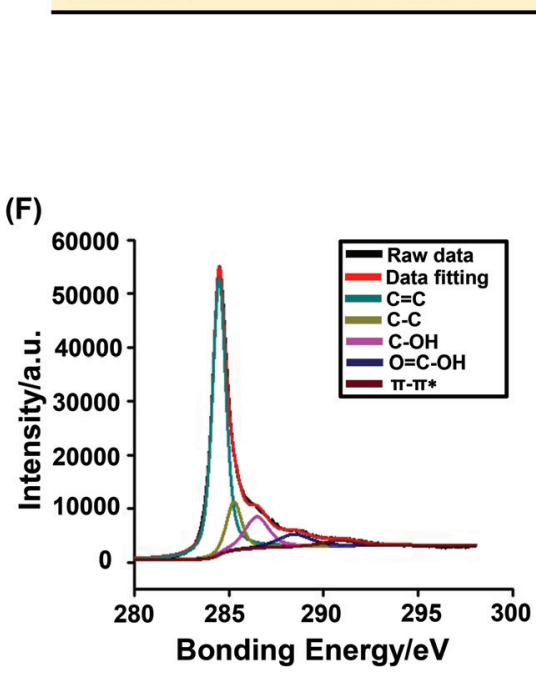

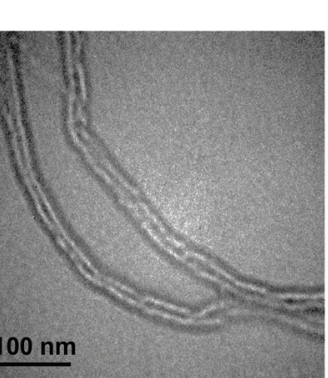

(B)

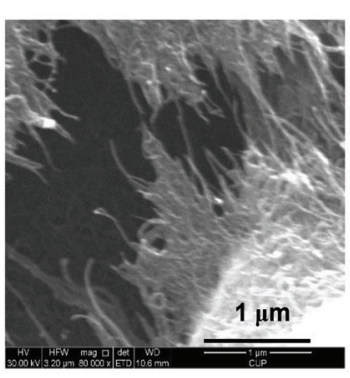

Zeta-potential Hydrodynamic (mV) diameter (nm)

$\begin{array}{ll}-21.2 \pm 2.68 & 100 \pm 0.96\end{array}$

$-25.10 \pm 0.94 \quad 661 \pm 31.14^{\#}$

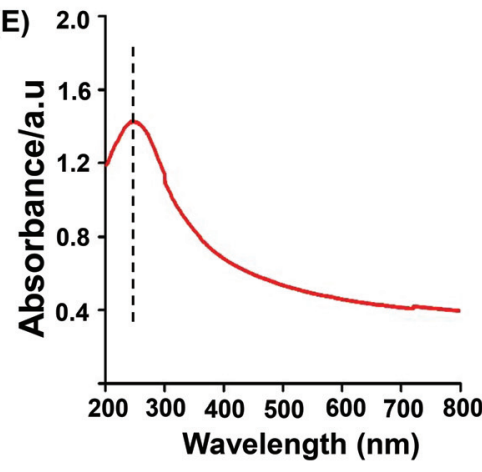

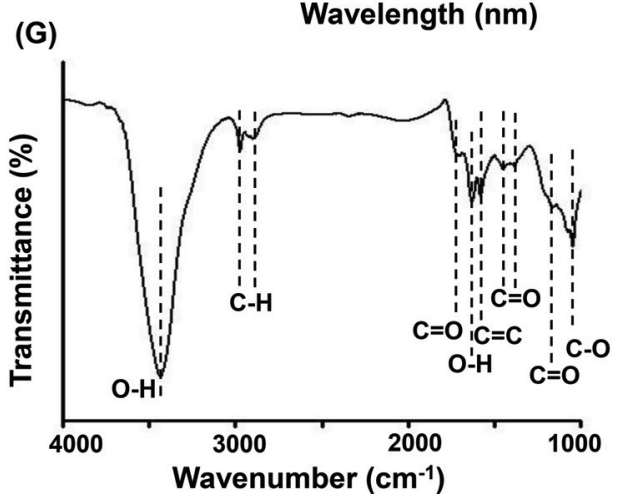

Fig. 1 Physicochemical characterization of MWCNTs-COOH. (A) Representative TEM images of MWCNTs- $\mathrm{COOH}$ (magnification: $20000 \times$ for the left panel and $300000 \times$ for the right panel). (B) A representative SEM image of MWCNTs-COOH with a magnification of $80000 \times$. (C) Histogram of MWCNT-COOH length distribution. The histogram was developed by counting 250 tubes $(n=250)$, with a Gaussian fit curve shown above. The average outer diameter and inner diameter are shown in the lower panel. (D) The zeta potential and hydrodynamic diameter of MWCNT-COOH samples measured in water, PBS and cell culture medium at $50 \mu \mathrm{g} \mathrm{mL}^{-1}(n=5)$. The pound sign (\#) indicates $P<0.001$, and the asterisk $(*)$ indicates $P<0.05$, compared to that measured in water, and the ampersand (\&) denotes $P<0.001$, compared to that measured in PBS. (E) The UV-vis spectrum of MWCNTs-COOH measured in water at $10 \mu \mathrm{g} \mathrm{mL}^{-1}$. (F) Characterization of the surface composition of MWCNTs-COOH by XPS. (G) Identification of functional groups on the MWCNT-COOH surface using the FTIR spectrum (range: $4000-1000 \mathrm{~cm}^{-1}$ ).

(Fig. 1D, $P<0.05$ ), likely due to enhanced dispersibility upon the formation of protein corona on tube surfaces in biological settings. $^{41,42}$

The zeta-potential measurements revealed that these materials were negatively charged in water, PBS and cell culture medium (Fig. 1D). Meanwhile, the addition of FBS induced a significant decrease of zeta-potential (Fig. 1D, $P<$ 0.001 ), presumably due to the formation of protein corona on tube surfaces. The UV-vis spectrum indicated a pronounced absorption peak at $245 \mathrm{~nm}$ with a shoulder peak at $\sim 300 \mathrm{~nm}$ 
(Fig. 1E), representative of the specific peaks for CNTs, as reported previously. ${ }^{43}$ Furthermore, XPS was performed to identify the surface composition of MWCNTs-COOH. Fig. 1F shows the spectrum of MWCNTs-COOH with three major peaks at 284.5, 285.2 and $290.5 \mathrm{eV}$, representing $\mathrm{C}=\mathrm{C}, \mathrm{C}-\mathrm{C}$, and $\pi \rightarrow \pi^{*}$ shake-up, respectively, which are attributed to their graphitic structure. ${ }^{44}$ There were two characteristic oxygenfunctional groups $\mathrm{C}-\mathrm{OH}$ (at $286.5 \mathrm{eV}$ ) and $\mathrm{O}=\mathrm{C}-\mathrm{OH}$ (at 288.9 eV) (Fig. 1F), consistent with published data. ${ }^{45,46}$ The FTIR spectrum further confirmed oxygenic groups on the surface of CNTs (Fig. 1G). The peaks at $3430 \mathrm{~cm}^{-1}$ and $1630 \mathrm{~cm}^{-1}$ denoted the absorbance of $\mathrm{O}-\mathrm{H}$ stretching vibrations, whereas bands representative of $\mathrm{C}-\mathrm{H}$ stretching were recognized at $2926 \mathrm{~cm}^{-1}$ and $2851 \mathrm{~cm}^{-1}$ (Fig. 1G). Meanwhile, the $\mathrm{C}=\mathrm{O}$ vibration band was indicated at $1060-1100 \mathrm{~cm}^{-1}$, and the band for the $\mathrm{C}=\mathrm{O}$ stretching vibration of $\mathrm{COOH}$ was identified at $1726 \mathrm{~cm}^{-1}$ (Fig. 1G). Additionally, bands indicative of $\mathrm{C}-\mathrm{O}$ stretching were located at $1053 \mathrm{~cm}^{-1}$ and $1069 \mathrm{~cm}^{-1}$, and the band for the stretching of conjugated $\mathrm{C}=\mathrm{C}$ was located at $1627 \mathrm{~cm}^{-1}$. These results together demonstrated that the physicochemical properties of our prepared MWCNT materials were similar to those of MWCNT materials used in the literature..$^{38,43,55}$

In this study, the heavy metal impurities in MWCNTs$\mathrm{COOH}$ (including $\mathrm{Al}, \mathrm{Ag}, \mathrm{Cd}, \mathrm{Hg}, \mathrm{Pb}, \mathrm{Cr}$ etc.) were all lower than $0.8 \mathrm{ppb}$, indicative of nearly no contamination of heavy metals. ${ }^{47,48}$ The average level of endotoxin in MWCNT samples was $0.095 \mathrm{EU} \mathrm{mL}^{-1}$, much lower than the U.S. FDA endotoxin threshold for purified water $\left(0.25 \mathrm{EU} \mathrm{mL}{ }^{-1}\right),{ }^{49,50}$ suggesting no significant endotoxin contamination in our samples. We also measured 15 EPA-PAHs (namely acenaphthene, acenaphthene, fluorine, phenanthrene, anthracene, fluoranthene, pyrene, benzo( $a$ )anthracene, chrysene, benzo $(b)$ fluoranthene, benzo $(k)$ fluoranthene, benzoapyrene, indeno(1,2,3-cd)pyrene, dibenz $(a, h)$ anthracene and benzoperylene) in MWCNTs-COOH and the concentration of PAHs in our sample was $31.55 \mathrm{ppb}$, less than the level in the vehicle control (47.21 ppb), excluding the possible contamination of PAHs in our samples. ${ }^{27,28}$

\section{MWCNTs stimulated systemic inflammation in mice}

To determine the pro-inflammatory responses caused by MWCNTs, we first looked into the levels of inflammatory cytokines in sera. It has been demonstrated that CNTs, owing to their fiber-like shape, are similar to asbestos. ${ }^{14,51,52}$ Compared to other delivery routes, I.V. administration is a more efficient method to understand the distribution and accumulation of MWCNTs in the whole body, and this route of administration is also an ideal model to understand the systemic immunological responses to the exposure of nanomaterials. It has been reported that CNTs could distribute to various orangs, such as the lung, liver, and spleen within $1 \mathrm{~h}$ after I.V. administration. ${ }^{53-55}$ In the current study, the exposure doses were selected based on biomedical application studies on CNTs as drug carriers, imaging agents, biosensors etc. ${ }^{56,57}$ The administration doses of CNTs in these studies usually ranged from 0.5 to $8 \mathrm{mg} \mathrm{kg}^{-1} \cdot{ }^{58,59}$ From the perspective of the safety assessment of MWCNTs used in biomedicine, our I.V. administration doses $\left(0.5-4 \mathrm{mg} \mathrm{kg}^{-1}\right)$ are comparable to the literature. Therefore, we screened 0.5, 1.0, 2.0 and $4.0 \mathrm{mg} \mathrm{kg} \mathrm{kg}^{-1}$ MWCNTs in mice through I.V. administration for 2 days. As shown in Fig. 2A and B, a great induction of inflammatory cytokines IL- 6 and TNF- $\alpha$ was observed in mice upon exposure to MWCNTs at various concentrations for 2 days, especially at $4.0 \mathrm{mg} \mathrm{kg}{ }^{-1}(P<0.001)$. Importantly, a clear dose dependence was found from 0.5 to $4.0 \mathrm{mg} \mathrm{kg}^{-1}$ (Fig. $2 \mathrm{~A}$ and B, $P<0.05$ ). Meanwhile, we performed CBC analysis to determine the systemic inflammatory responses caused by MWCNTs. Fig. 2C shows a significant increase of the counts of total white blood cells (WBCs), lymphocytes (LYM) and neutrophils (NE) in a dose-dependent manner (Fig. 2C, $P<0.05$ ), especially for $4.0 \mathrm{mg}$ per $\mathrm{kg}$ body weight, in agreement with the induction of pro-inflammatory cytokines (Fig. 2A and B). Additionally, the count of platelets (PLT) in peripheral blood was significantly reduced in mice challenged by MWCNTs in a dose-dependent manner, relative to that of untreated mice $(P<0.05)$, indicating the depletion of PLT by MWCNTs in peripheral blood due to the formation of CNT-biomolecule complexes (e.g. clotting). ${ }^{60}$ Thereafter, MWCNT-induced effects were closely monitored over time. The pro-inflammatory responses lasted for 14 days after a single MWCNT administration, as characterized by the gradual decline of serum IL- 6 concentration from $6 \mathrm{~h}$ to $12 \mathrm{~h}, 24 \mathrm{~h}, 48 \mathrm{~h}$ and 7 days until 14 days to the baseline (Fig. 2D).

In addition, we also looked at the inflammatory responses in the spleen, because the spleen is a major immune organ in the response to diverse exogenous stimuli. ${ }^{61}$ Fig. $2 \mathrm{E}$ shows an enlargement of the spleen size for mice after MWCNT treatment for 14 days, indicative of the occurrence of splenomegaly, compared to untreated mice. Furthermore, we analyzed the inflammatory responses by studying the infiltration of inflammatory cells through FACS analysis. As shown in Fig. 2F, the number of F4/80-positive cells (referring to macrophages ${ }^{36}$ ) was greatly increased by $>50 \%$ in spleens from MWCNTtreated mice, compared to that in spleens from untreated mice $(P<0.05)$. Collectively, these results showed the great proinflammatory capability of MWCNTs.

\section{MWCNTs provoked infiltration of pro-inflammatory cells in the synovium and meniscus within knee joints}

Since the toxicity to primary target organs (e.g. liver and lung) has been extensively investigated so far, we herein investigated MWCNT toxicity from a new angle by focusing on the effects on joints under MWCNT exposure. We did not find any abnormal alterations to the joints in mice after 2 day exposure through the histological examination. By contrast, as shown in Fig. 3A, histological examination showed increased thickness of the synovial membrane within knee joints of MWCNT-treated mice after 14 day exposure (shown by arrows), due to the infiltration of pro-inflammatory cells in the synovium and meniscus. However, no MWCNTs could be found within the knees through histological exam- 
(A)

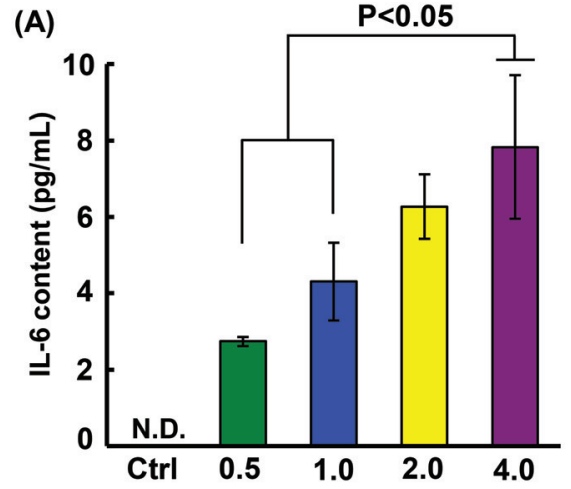

(B)

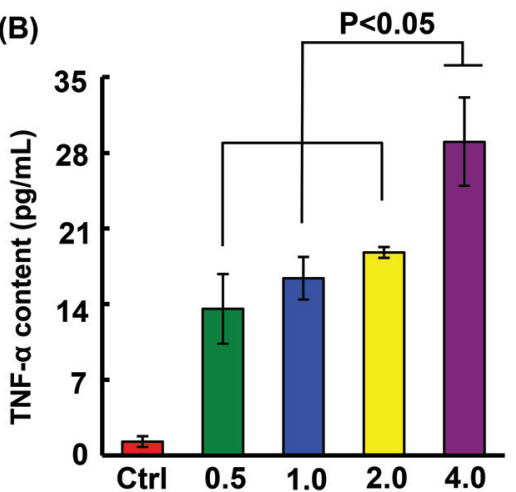

(C)

\begin{tabular}{|c|c|c|c|c|c|}
\hline \multirow{2}{*}{$\begin{array}{c}\text { CBC } \\
\text { Indexes }\end{array}$} & \multirow{2}{*}{$\begin{array}{c}\text { Untreated } \\
\text { Control }\end{array}$} & \multicolumn{4}{|c|}{ MWCNTs-COOH (mg/kg body weight) } \\
\cline { 3 - 6 } & & 0.5 & 1.0 & 2.0 & 4.0 \\
\hline WBC (109/L) & $2.80 \pm 0.44$ & $3.78 \pm 0.53$ & $4.28 \pm 0.87$ & $3.68 \pm 0.27$ & $5.27 \pm 0.84^{*}$ \\
\hline LYM (10\%/L) & $2.13 \pm 0.46$ & $3.05 \pm 0.48$ & $2.95 \pm 0.67$ & $2.77 \pm 0.34$ & $4.07 \pm 0.74^{*}$ \\
\hline NE (109/L) & $0.67 \pm 0.03$ & $0.72 \pm 0.05$ & $0.87 \pm 0.19$ & $0.90 \pm 0.13$ & $1.15 \pm 0.07^{*}$ \\
\hline PLT (10\%/L) & $449 \pm 23.70$ & $484.50 \pm 37.04$ & $330 \pm 14.32^{*}$ & $259.33 \pm 29.84^{\#}$ & $226 \pm 14.10^{*}$ \\
\hline
\end{tabular}

(D)

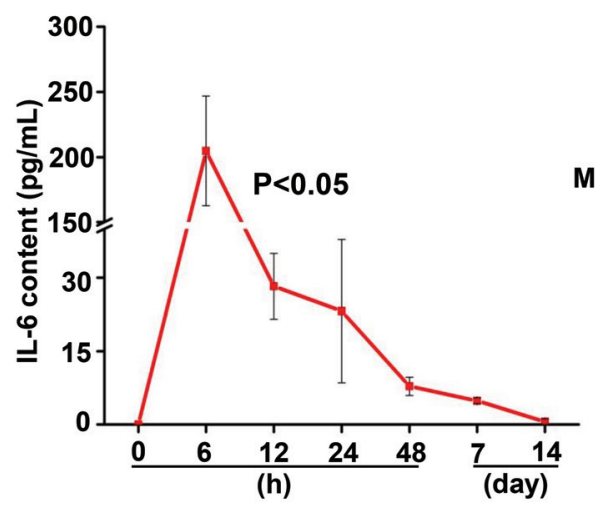

(E)
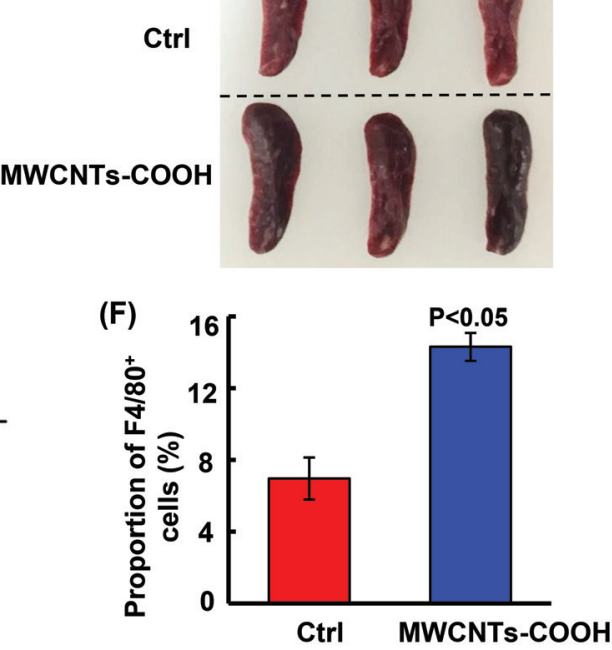

Fig. 2 MWCNTs induced systemic inflammation in animals. Following I.V. MWCNT administration at 0.5, 1.0, 2.0 and $4.0 \mathrm{mg}$ per kg body weight for 2 days, the peripheral blood were collected for cytokine and CBC determination. The concentrations of IL- 6 (A) and TNF- $\alpha$ (B) in sera ( $n=6)$. (C) CBC analysis for peripheral blood from mice following MWCNT administration for 2 days $(n=6)$. (D) Concentrations of IL-6 in sera from mice upon $4.0 \mathrm{mg}$ per $\mathrm{kg}$ body weight MWCNT administration over the time course $(n=6)$. (E) Images of spleens from mice with or without MWCNT-COOH administration at $4.0 \mathrm{mg}$ per $\mathrm{kg}$ body weight for 14 days. (F) The proportion of F4/80 positive cells in the total non-erythroid cells in splenic single cell suspensions from mice with or without MWCNT administration at $4.0 \mathrm{mg}$ per kg body weight for 14 days $(n=5)$. The asterisk (*) indicates $P<0.05$, and the pound sign (\#) denotes $P<0.001$, compared to the untreated control.

ination and TEM analysis (Fig. 3A and B), ruling out the likelihood of the intrusion of MWCNTs into knees. In stark contrast to knees, dark dots (representative of CNTs) could be visualized in livers and lungs from mice treated with
MWCNTs-COOH for 14 days (denoted by arrows in Fig. 3C), indicating the accumulation of CNTs in the liver and lung, consistent with previous reports. ${ }^{62-64}$ These observations were further verified by histological examination of sections 
(A)

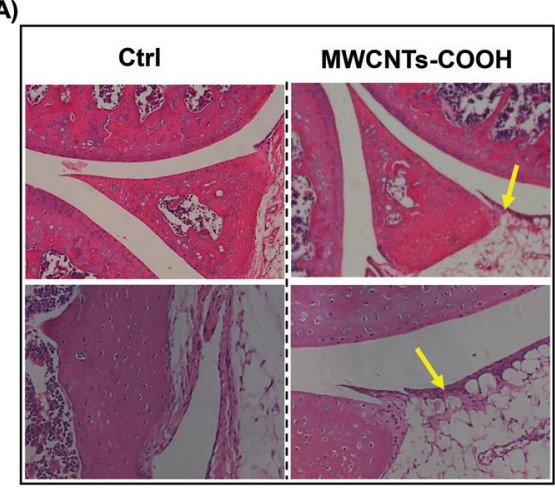

(B)

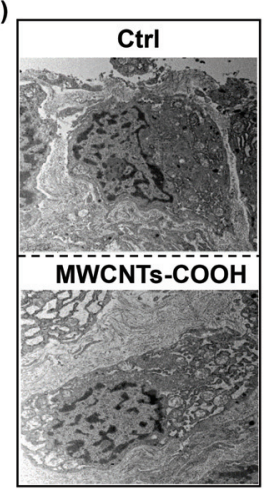

(C)

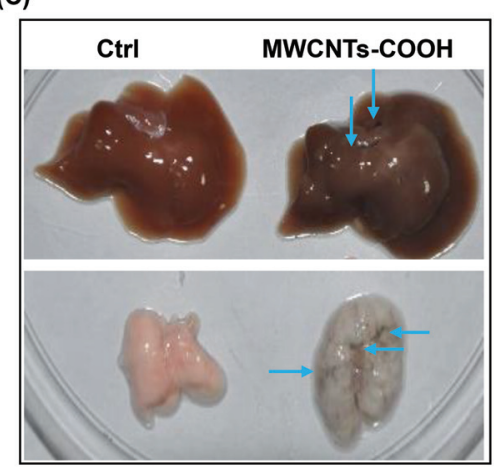

(D)

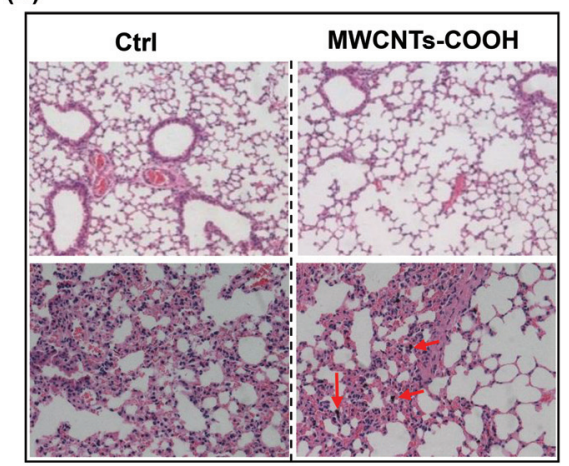

(E)

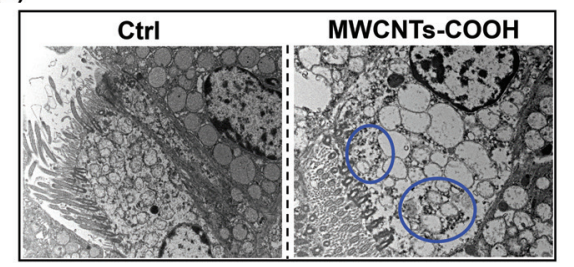

Fig. 3 MWCNT exposure stimulated synovial inflammation within knee joints. Following MWCNT administration at $4.0 \mathrm{mg}$ per $\mathrm{kg}$ body weight in mice for 14 days, liver, lung and knee specimens were collected for the following assays. (A) Representative images of knee joints with H\&E staining. Yellow arrows denote the synovial membrane. Original magnification, $\times 100$ (the upper panel) and $\times 200$ (the lower panel). (B) Representative TEM images of knee sections. Original magnification, $\times 15000$. (C) Representative liver and lung images. Arrows indicate CNT deposition (shown in black dots) in the liver and lung from MWCNT-treated mice. (D) Lung images with H\&E staining. Original magnification, $\times 100$ (the upper panel) and $\times 200$ (the lower panel). Red arrows indicate the accumulation of CNTs in pulmonary alveoli. (E) Representative TEM images of lung sections. Original magnification, $\times 15$ 000. Blue circles indicate CNT aggregates.

from lungs of MWCNT-exposed mice (Fig. 2D, denoted by arrows), in parallel with previous results that demonstrated that the liver and lung are the prominent sites for nanoparticle accumulation. ${ }^{63,65,66}$ TEM examination confirmed the accumulation of MWCNTs within alveolar cells (represented by circles in Fig. 3E).

Despite the absence of the direct distribution of MWCNTs into knees, these results indicated significant synovial inflammation within knees, diagnostic of synovial inflammation. ${ }^{67,68}$ To substantiate this finding, immunohistochemistry results demonstrated there was a great increase of COX-2 and MMP-9 concentrations in knee sections from MWCNT-treated mice, as shown in Fig. 4A and B. The content of COX-2 and MMP-9 was increased by 2.2-fold and 2.6-fold in MWCNT-treated mice, relative to untreated mice, respectively $(P<0.05)$. Arthritis is accompanied by increased cell death within and under joint cartilage. ${ }^{69-71}$ Thus, we studied cell death by staining the knee sections using the TUNEL assay. As shown in Fig. 4C, a remarkable increase of the number of apoptotic cells (stained in claybank color, shown in the red circled area) was visualized in knee sections from MWCNT-treated mice relative to untreated mice $(P<0.05)$, representative of arthritis syndrome. With these multiple lines of evidence, we could conclude that MWCNTs triggered significant synovial inflammation and articular cartilage degeneration within knees after 14 day exposure, diagnostic of arthritis syndrome. ${ }^{67,68}$ 
(A)

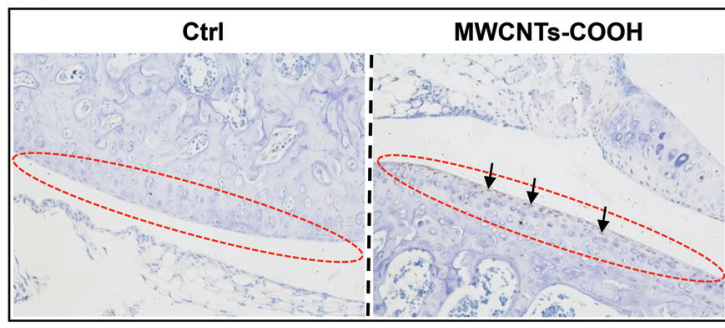

(B)

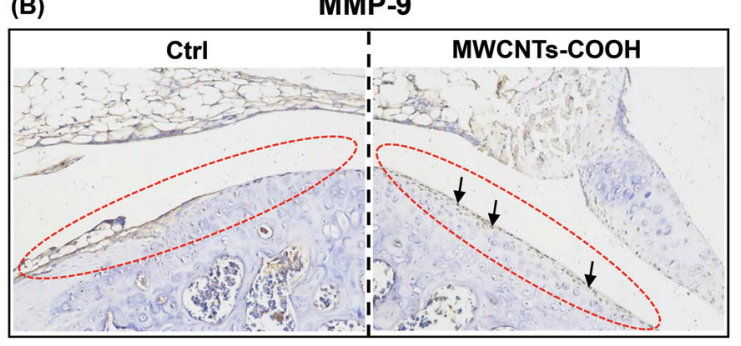

(C)

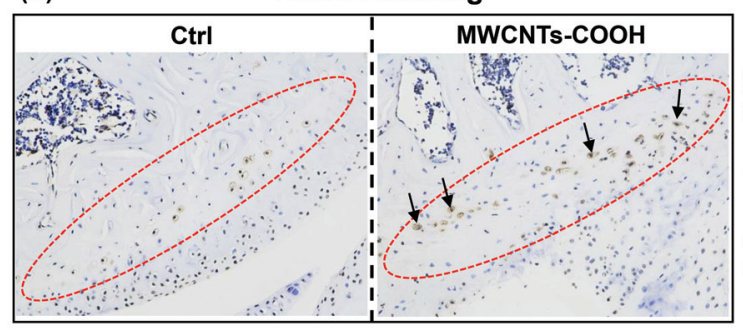

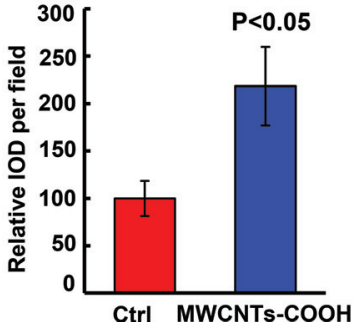
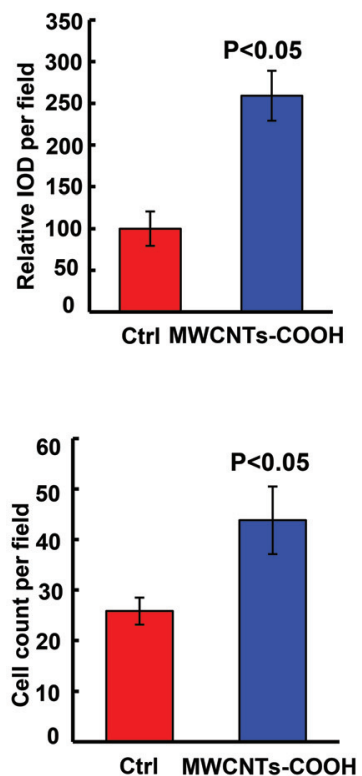

Fig. 4 MWCNT exposure induced joint degeneration. Following MWCNT administration at $4.0 \mathrm{mg}$ per kg body weight in mice for 14 days, knee specimens were subjected to immunohistochemistry. (A) Immunohistochemical staining of knee sections with an Ab against COX-2. Original magnification, $\times 200$. Quantitative data for IOD of COX-2 positive area per field are shown in the right panel $(n=6)$. (B) Immunohistochemical staining of knee sections with an Ab against MMP-9. Original magnification, $\times 200$. Quantitative data for IOD of MMP-9 positive area per field are shown in the right panel $(n=6)$. (C) Images of TUNEL staining of knee sections. Quantitative data for the number of TUNEL staining-positive cells per field $(n=6)$ are shown in the right panel. Red circles show the articular surface for analysis. Arrows denote positive cells.

\section{MWCNTs induced pro-inflammatory responses in} macrophages by activating TLR4-NF-кB signaling

To elucidate the molecular basis underlying MWCNTinduced pro-inflammatory responses, we studied the signaling pathway for activation of macrophages by MWCNTs in THP-1 macrophages. ${ }^{72}$ We endeavored to avoid dramatic cell death and thus carried out the in vitro experiments at relatively low concentrations. The cytotoxicity screening was performed in THP-1 cells upon treatment with MWCNTs at various concentrations through the Live/Dead assay. There was a dosedependent toxicity to THP-1 cells upon treatment with MWCNTs from 1 to $80 \mu \mathrm{g} \mathrm{mL}{ }^{-1}$; only mild toxicity was demonstrated in these cells below $40 \mu \mathrm{g} \mathrm{mL}^{-1}$ (Fig. 5A). To verify the finding on cytotoxicity, cell division was evaluated by the BrdU assay. As shown in Fig. 5B, MWCNTs inhibited replication of THP-1 cells in a dose-dependent manner from 20 to $80 \mu \mathrm{g}$ $\mathrm{mL}^{-1}(P<0.001)$, in analogy to the cytotoxicity results (Fig. 5A). Furthermore, the production of ROS was assayed in cells responding to MWCNTs with a DCF-DA probe. No significant intracellular ROS generation was induced in THP-1 cells treated with MWCNTs at $10 \mu \mathrm{g} \mathrm{mL}^{-1}$, whereas ROS production was elevated upon treatment with 20 or $40 \mu \mathrm{g} \mathrm{mL}{ }^{-1}$ MWCNTs, especially the latter concentration (Fig. 5C, $P<0.001$ ). To discriminate the mechanism responsible for cytotoxicity induced by MWCNTs, cell death was assessed through FACS analysis after FITC-conjugated Annexin V and PI staining. The FACS results indicated that MWCNTs promoted the increase of Annexin V and PI double positive cells (namely Annexin $\mathrm{V}^{+} \mathrm{PI}^{+}$) in a dose-dependent manner (Fig. 5D, $P<0.05$ ). Of note, no increase of the number of PI single positive cells was found in cells under MWCNT treatment. Additionally, pronounced morphological alterations of THP-1 cells occurred upon MWCNT-COOH treatment at 20 or $40 \mu \mathrm{g} \mathrm{mL} \mathrm{m}^{-1}$, as characterized by the occurrence of collapse in the cellular body and reduced surface protrusions, especially for cells treated with $40 \mu \mathrm{g} \mathrm{mL} \mathrm{m}^{-1}$ MWCNTs-COOH (Fig. 5E), suggestive of cytotoxicity to THP-1 cells. Together, these results demonstrated that MWCNTs provoke cell death through the apoptotic mechanism, and oxidative stress is an important mechanism 
(A)

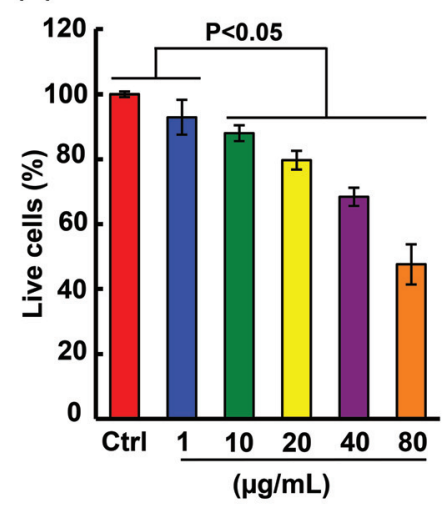

(D)
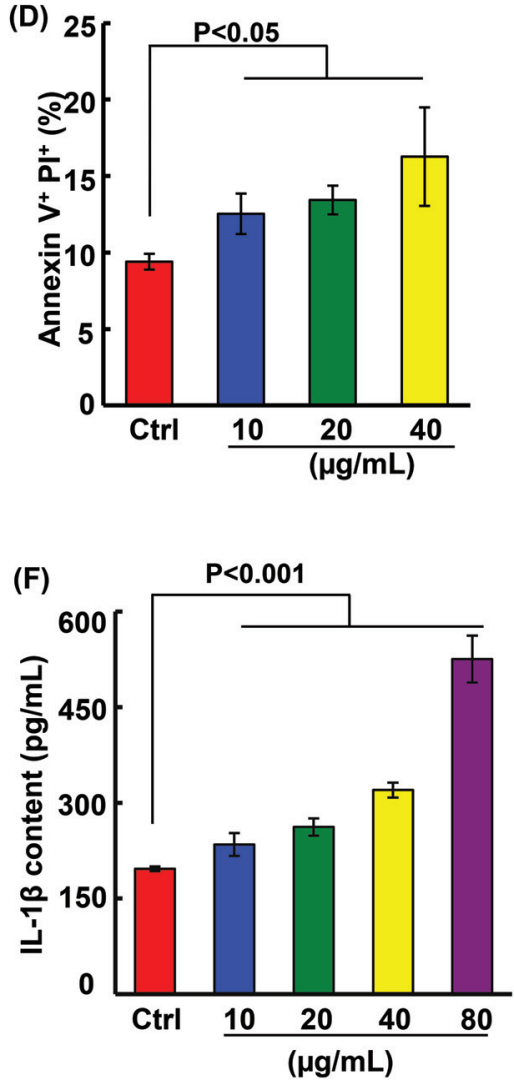

(B)

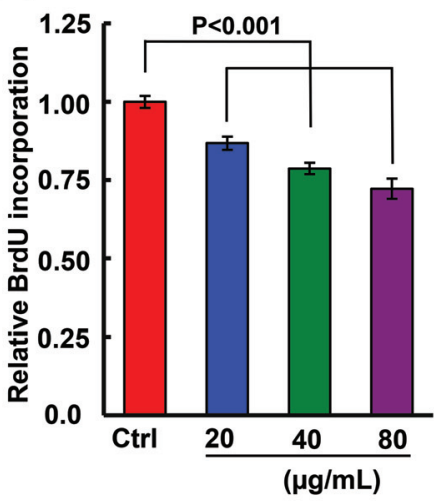

(C)

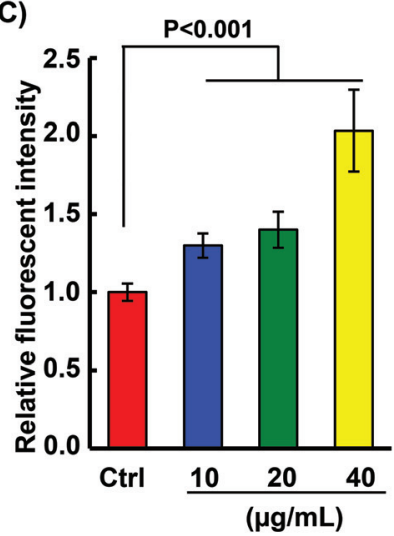

(E)

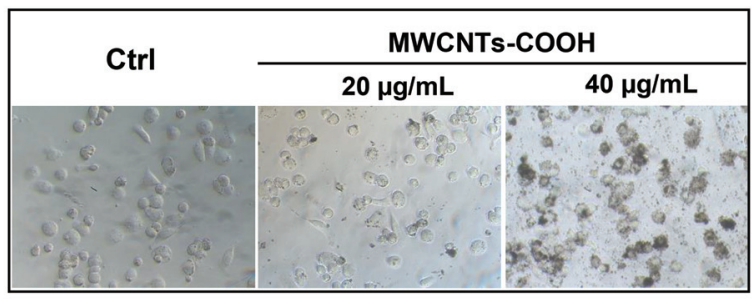

(G)

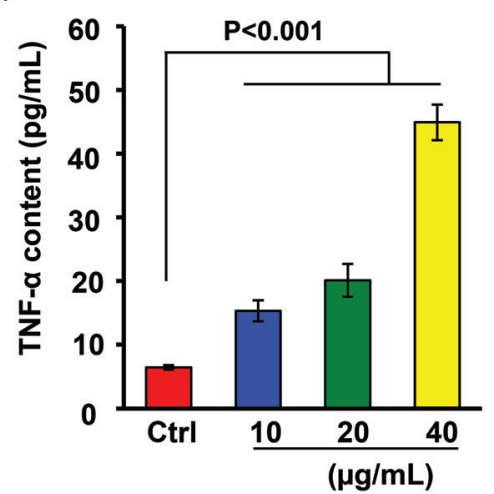

Fig. 5 MWCNTs induced macrophage activation. (A) Cell viability of THP-1 cells upon exposure to MWCNTs for $24 \mathrm{~h}$ at various concentrations determined by LIVE/DEAD viability/cytotoxicity assay $(n=6)$. (B) Relative BrdU incorporation of THP-1 cells upon exposure to $20,40,80 \mu g \mathrm{~mL}^{-1}$ MWCNTs for $24 \mathrm{~h}$. (C) Intracellular ROS production in THP-1 cells upon 10, 20, and $40 \mu \mathrm{g} \mathrm{mL}^{-1}$ MWCNTs treatment at $24 \mathrm{~h}(n=6)$. (D) The percentage of apoptotic cells was determined through FACS analysis of FITC-Annexin V and PE-PI double positive THP-1 cells upon 10, 20 , and $40 \mu \mathrm{g} \mathrm{mL}{ }^{-1}$ MWCNT treatment for $24 \mathrm{~h}$. Data were acquired from 20000 cells per sample $(n=6)$. (E) Morphological characterization of THP-1 cells responding to MWCNT treatment at 20 and $40 \mu \mathrm{g} \mathrm{mL} \mathrm{L}^{-1}$ for $24 \mathrm{~h}$. Original magnification, $\times 200$. (F, G) The protein concentrations of IL-1 $\beta(\mathrm{F})$ and TNF- $\alpha(\mathrm{G})$ secreted in cell culture medium were assayed through ELISA $(n=6)$.

responsible for this toxicity, in agreement with previous findings that suggested that oxidative stress is a mechanism responsible for CNT-induced toxicity ${ }^{73,74}$ to macrophages and their pro-inflammatory activation. ${ }^{75-77}$

Despite the mild cytotoxicity to THP-1 cells induced by MWCNTs below $40 \mu \mathrm{g} \mathrm{mL} \mathrm{m}^{-1}$, MWCNTs still significantly induced the production of pro-inflammatory cytokines, similar to previous results. ${ }^{78}$ As shown in Fig. $5 \mathrm{~F}$ and G, a significant increase of IL- $1 \beta$ and TNF- $\alpha$ concentrations was found in THP-1 cells upon MWCNT treatment, and this increase showed a dose-dependency $(P<0.001)$.

NF- $\mathrm{KB}$ signaling plays a key role in the activation and amplification of inflammation. ${ }^{79,80}$ Receptors located on the macrophage membrane ${ }^{81}$ have been verified to discriminate specific 
components of invading pathogens. $^{82}$ Of them, TLR4, a member of toll-like receptors, ${ }^{83}$ has been reported to sense the stimulation of graphene oxide and trigger the activation of the NF- $\kappa$ B pathway. ${ }^{31,50}$ To determine whether MWCNTs initiated pro-inflammatory responses by activating the TLR4-NF- $\mathrm{BB}$ signaling, selective inhibitors for TLR4 and NF- $\mathrm{\kappa B}$ were used for pre-treatment in cells exposed to MWCNTs. As shown in Fig. 6A, the TLR4 inhibitor CLI-095 considerably suppressed the induction of TNF- $\alpha$ in THP- 1 cells by $79 \%$ upon MWCNT treatment $(P<0.01)$, compared to the untreated group, suggesting an important role of TLR4 in sensing the association of MWCNTs onto the plasma membrane. To confirm the regulation of TNF- $\alpha$ induction by MWCNTs dependent on the TLR4 molecule and its associated NF-кB signaling, we assessed
TNF- $\alpha$ expression in HEK293-TLR4 cells $^{30,50}$ (which have the artificial TLR4 complex knock-in) responding to MWCNTs. LPS was used as a positive control to trigger the TLR4 signaling, ${ }^{84}$ which increased TNF- $\alpha$ expression up to 50 -fold in HEK293-TLR4 cells (Fig. 6B, $P<0.001$ ), demonstrating that these cells were ideal for studying TLR4 activation. As shown in Fig. 6C, MWCNTs greatly activated TLR4-induced signaling, leading to a substantial stimulation of TNF- $\alpha$ expression by more than 28-fold in HEK293-TLR4 cells upon $20 \mu \mathrm{g} \mathrm{mL}$ MWCNT treatment and by more than 44-fold in cells upon $40 \mu \mathrm{g} \mathrm{mL}{ }^{-1}$ MWCNT treatment, compared to untreated cells $(P<0.001)$.

Upon activation of NF- $\kappa \mathrm{B}$ signaling, I $\kappa \mathrm{B}$ is thus phosphorylated for ubiquitin-dependent proteasomal degradation, which
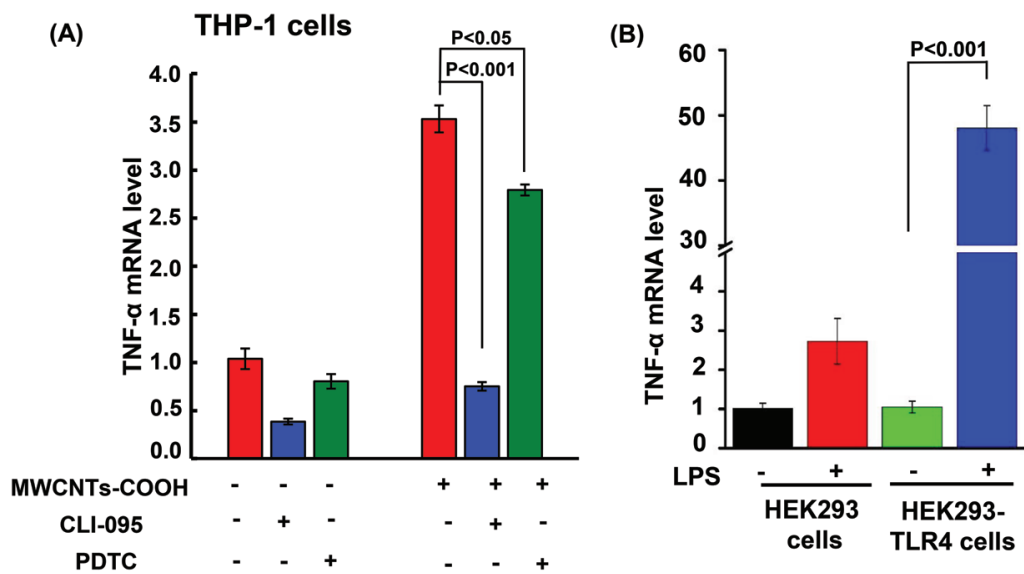

(C)

HEK293-TLR4 cells $\mathrm{P}<0.001$
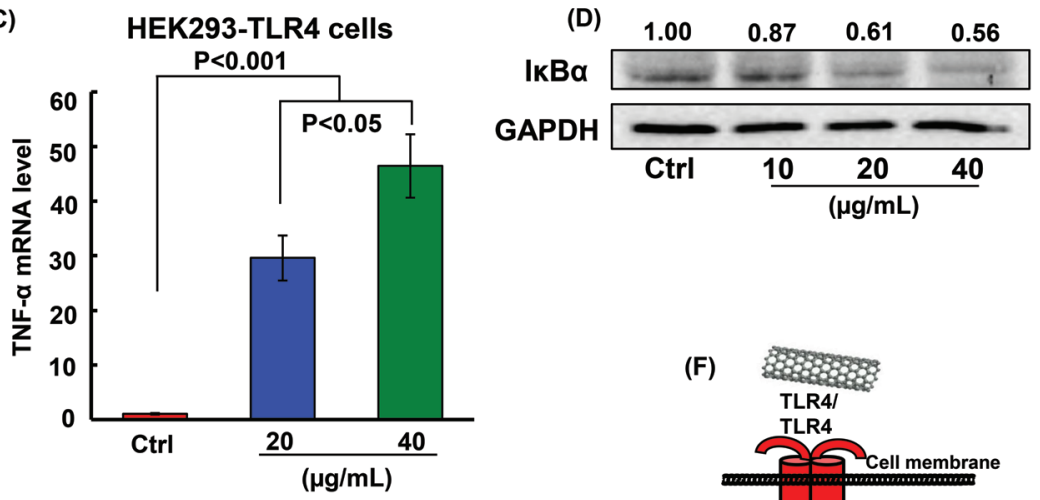

(E)
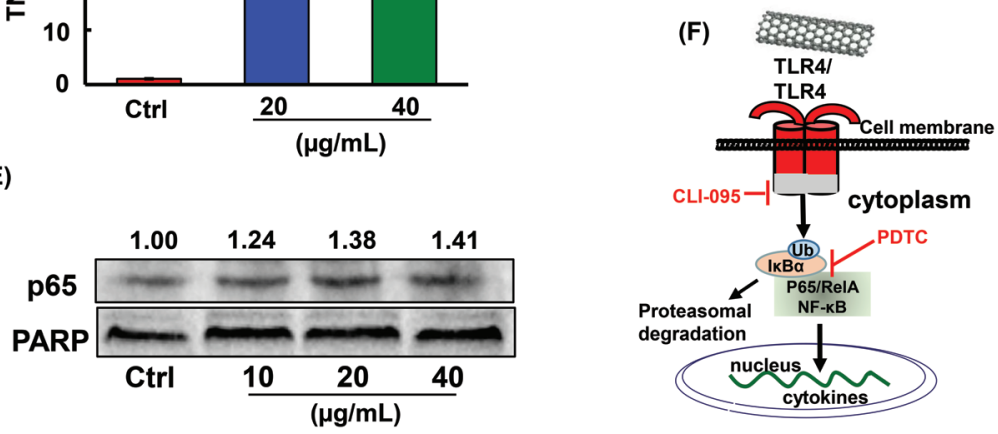

Fig. 6 The activation of TLR4-NF- $\mathrm{kB}$ signaling in response to MWCNT treatment. (A) TNF- $\alpha$ expression in THP-1 cells treated with MWCNTs at $20 \mu \mathrm{g} \mathrm{mL} \mathrm{L}^{-1}$ for $12 \mathrm{~h}$ with or without pre-treatment of CLI-095 or PDTC $(n=6)$. (B) TNF- $\alpha$ expression in HEK293 cells and HEK293-TLR4 cells in response to LPS $\left(1 \mu \mathrm{g} \mathrm{mL}^{-1}\right)$ for $12 \mathrm{~h}(n=6)$. (C) TNF- $\alpha$ level in HEK293-TLR4 cells upon treatment with 20 and $40 \mu \mathrm{g} \mathrm{mL} \mathrm{m}^{-1}$ of MWCNTs for $24 \mathrm{~h}$ $(n=6)$. (D) IKB $\alpha$ concentration in the total cellular proteins extracted from THP-1 cells upon MWCNTs-COOH treatment for $24 \mathrm{~h}$ by Western blotting. (E) Western blotting results of p65 content in the nuclear portion of THP-1 cells treated with MWCNTs-COOH for $24 \mathrm{~h}$. (F) A schematic diagram depicting MWCNT-stimulated activation of TLR4-NF- $\mathrm{kB}$ signaling. The action sites of TLR4 and NF- $\mathrm{kB}$ inhibitors are indicated (CLI-095 for TLR4 and PDTC for NF-kB). 
promotes p65/RelA translocation from the cytoplasm into the nucleus, resulting in enforced transcription of downstream targeted genes. ${ }^{83,85}$ We therefore studied the activation of NF- $\mathrm{KB}$ signaling by determining the changes of IкB $\alpha$ and p 65 concentrations. A reduction of $\mathrm{I} \kappa \mathrm{B} \alpha$ concentration was observed in MWCNT-treated cells, in a dose-dependent manner, from 10 to 20 and $40 \mu \mathrm{g} \mathrm{mL} \mathrm{m}^{-1}$, relative to untreated cells (Fig. 6D). On the contrary, an increase of p65 was found in the nuclear portion of MWCNT-treated cells, compared to the untreated control (Fig. 6E), analogous to previous findings. ${ }^{31}$ To further substantiate the involvement of NF- $\kappa$ B activation in MWCNTstimulated pro-inflammatory responses, a selective NF- $\mathrm{B}$ inhibitor, pyrrolidine dithiocarbamate (PDTC, as depicted in Fig. 6A), was used to pretreat cells prior to MWCNT treatment. As shown in Fig. 6A, PDTC pre-treatment repressed the induction of TNF- $\alpha$ expression by approximately $20 \%$ in cells responding to MWCNTs, relative to treated cells without PDTC pre-treatment $(P<0.05)$. Owing to the activation of NF- $\kappa \mathrm{B}$ signaling, the expression of its downstream target genes (IL-1 $\beta$ and TNF- $\alpha)^{86-88}$ would be enhanced, leading to the generation of pro-interleukin cytokines, as described above in Fig. 5F and G. Collectively, our findings together verified the crucial role of TLR4-NF- $\kappa \mathrm{B}$ signaling in sensing MWCNTs and in initiating the pro-inflammatory responses in macrophages upon MWCNT treatment (Fig. 6D).

\section{MWCNTs provoked macrophages to alter the cellular metabolism of synoviocytes and chondrocytes}

Based on the above results, we hypothesized that MWCNTinduced pro-inflammatory responses accounted for synovial inflammation and consequential disordered cellular metabolism within knee joints. To test this hypothesis, we developed an in vitro approach for this purpose (a schematic is depicted in Fig. 7A): the culture medium from THP-1 cells with or without MWCNT treatment was used to treat synoviocytes and chondrocytes. A dose-dependent cytotoxicity was also observed in synoviocyte SW-982 cells and chondrocyte SW-1353 cells (ESI Fig. $1 \dagger$ ). Compared to THP-1 cells (Fig. 5A), SW-982 cells and SW-1353 cells, two matrix cells, were less sensitive to the stimulation of MWCNTs-COOH, with approximately $70 \%$ cells remaining alive at the highest concentration of $200 \mu \mathrm{g} \mathrm{mL}$ (ESI Fig. 1A and $\mathrm{B} \dagger$ ). Afterwards, the expressions of cyclooxygen-ase-1 (COX-1) and COX-2 and MMP-1, -2, -3, and -9 were assessed in SW-982 human synoviocytes (an established cell line for joint-related studies ${ }^{89}$ ) following incubation with culture medium from MWCNT-treated THP-1 cells. The members of the COX and MMP families play pivotal roles in the destruction of articular cartilage. ${ }^{90}$ Therefore, MMP and COX members are widely used surrogates to evaluate synovial cell activation and metabolic status, and the elevated levels of these surrogates demonstrated pathological activation of synovial cells, which are associated with destruction of articular cartilage and marginal bone. ${ }^{90,91}$ As shown in Fig. 7B, all these genes were considerably induced in SW-982 synoviocytes following incubation with culture medium from MWCNT-treated THP-1 cells, compared to that in SW-982 cells with culture
(A)

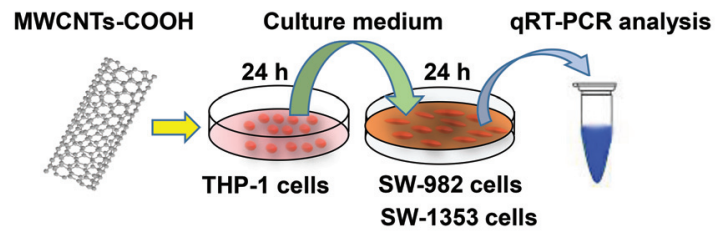

(B)

\begin{tabular}{|c|c|c|}
\hline $\begin{array}{c}\text { Target } \\
\text { Genes }\end{array}$ & $\begin{array}{c}\text { THP-1 medium without } \\
\text { MWCNT treatment }\end{array}$ & $\begin{array}{c}\text { THP-1 medium with } \\
\text { MWCNT treatment }\end{array}$ \\
\hline MMP-1 & $1.00 \pm 0.09$ & $9.80 \pm 1.16^{*}$ \\
\hline MMP-2 & $1.00 \pm 0.07$ & $1.64 \pm 0.17^{*}$ \\
\hline MMP-3 & $1.00 \pm 0.11$ & $6.02 \pm 1.00^{*}$ \\
\hline MMP-9 & $1.00 \pm 0.39$ & $14.21 \pm 1.55^{*}$ \\
\hline COX-1 & $1.00 \pm 0.13$ & $2.59 \pm 0.72 *$ \\
\hline COX-2 & $1.00 \pm 0.07$ & $3.57 \pm 0.60 *$ \\
\hline
\end{tabular}

Fig. 7 MWCNT-induced macrophagic inflammation activated synovial cells. (A) A schematic diagram delineating the study of stimulating effects of the culture medium from THP-1 cells on SW-982 cells. (B) The relative expression of MMP-1, MMP-2, MMP-3, MMP-9, COX-1 and COX-2 in SW-982 cells following incubation with the culture medium from MWCNT-treated THP-1 cells (at $40 \mu \mathrm{g} \mathrm{mL}^{-1}$ ) for $24 \mathrm{~h}(n=6)$.

medium from THP-1 cells without MWCNT treatment $(P<$ $0.05)$. In support of these data, the concentrations of both proMMP-2 (72 kDa) and mature MMP-2 (62 kDa) were largely increased in SW-982 cells following incubation with culture medium from MWCNT-treated THP-1 cells, especially for cells following incubation with the medium from MWCNT-treated THP-1 cells at $80 \mu \mathrm{g} \mathrm{mL} \mathrm{m}^{-1}$ (lane 3 ), relative to SW-982 cells with the medium from THP-1 cells with no MWCNT-COOH treatment (Fig. 8A). Moreover, the enzymatic activities of MMP-2 and MMP-9 were markedly enhanced in SW-982 cells following incubation with culture medium from MWCNTtreated THP-1 cells, especially at $80 \mu \mathrm{g} \mathrm{mL} \mathrm{m}^{-1}$ (lane 3), as evidenced by gelatin zymography. ${ }^{34,92}$ Gelatin zymography is still a standard method to determine the activities of MMPs, because this assay could directly reflect the amount of gelatin digested by MMPs. ${ }^{93-95}$ Culture medium from LPS-treated THP-1 cells was used as a positive control. It should also be noted that direct treatment with MWCNTs or LPS did not change the MMP-2 level and the enzymatic activities of MMP-2 and MMP-9 (92KD) (Fig. 8A and B).

Furthermore, we also evaluated the MMPs levels using ELISA. As shown in Fig. 8C, the concentration of MMP-3 secreted from SW-982 cells was significantly increased by $>2$ fold and $>4$-fold in cells incubated with the medium from MWCNT-treated THP-1 cells at 20 and $40 \mu \mathrm{g} \mathrm{mL}{ }^{-1}$, respectively, compared to that in SW-982 cells incubated with culture medium from THP-1 cells not treated with MWCNT $(P<0.05)$. These data thus suggested that MWCNT-stimulated proinflammatory cytokines activated synovial cells and altered their cellular priming status.

Additionally, chondrocytes also participate in degrading its own matrix by releasing autocrine-paracrine factors under inflammatory conditions, such as COX and MMP members, 
(A)
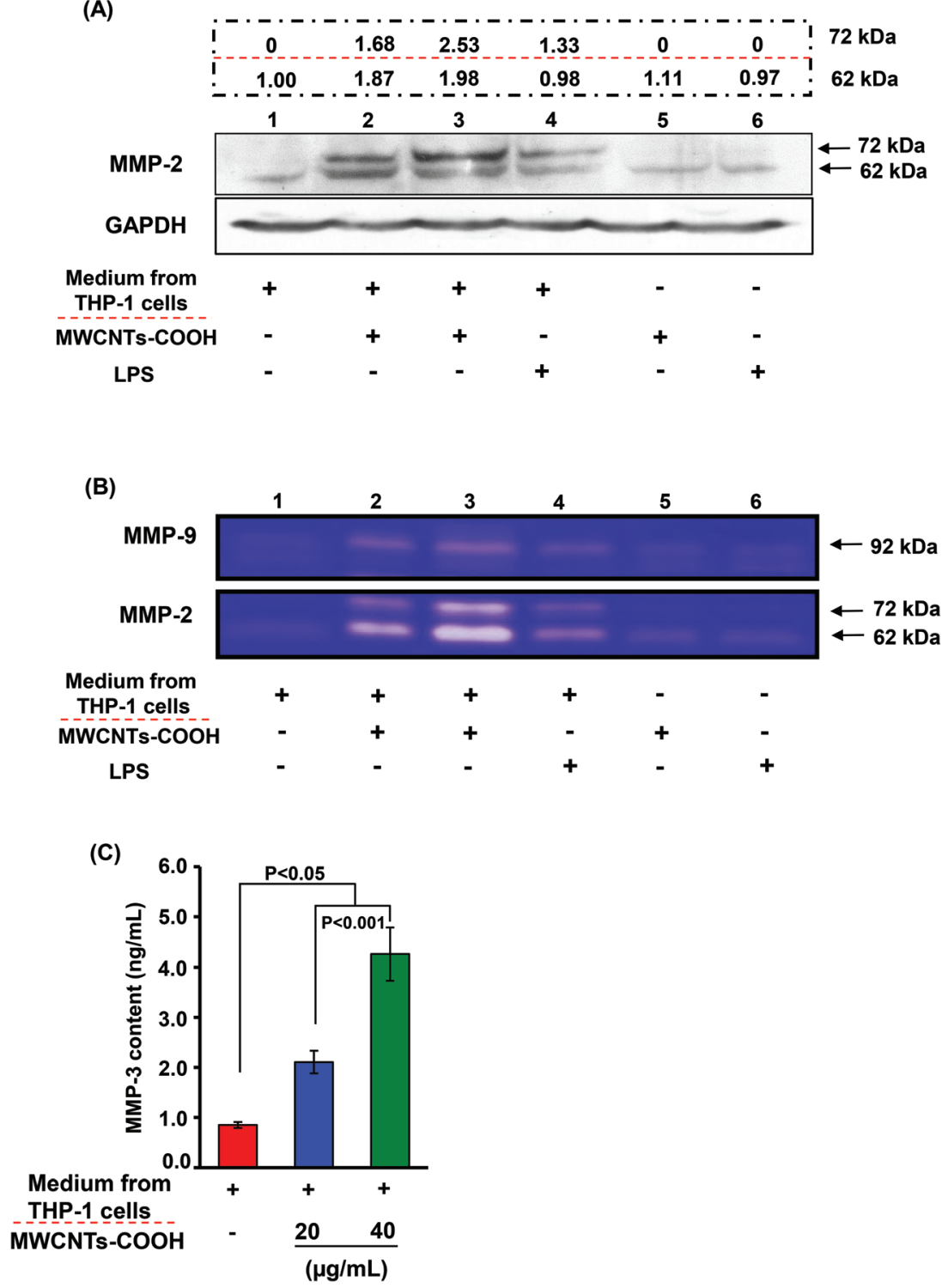

Fig. 8 MWCNT-induced inflammation enhanced MMP activation. (A) Western blotting analysis of MMP-2 level in SW-982 cells following incubation with cell culture medium from MWCNT-treated THP-1 cells at $40 \mu \mathrm{g} \mathrm{mL} \mathrm{L}^{-1}$ for $24 \mathrm{~h}$. The $72 \mathrm{kDa}$ band indicates pro-MMP-2, and the $62 \mathrm{kDa}$ band denotes mature MMP-2. (B) Representative gelatin zymography data showed the enzymatic activities of MMP-9 and MMP-2 secreted by SW-982 cells in response to different culture media for $24 \mathrm{~h}$. For (A) and (B), lane 1, control; lanes 2-4, treatment with supernatants collected from THP-1 cells upon 40 and $80 \mu \mathrm{g} \mathrm{mL} \mathrm{m}^{-1} \mathrm{MWCNTs}-\mathrm{COOH}$ or $1 \mu \mathrm{g} \mathrm{mL} \mathrm{m}^{-1} \mathrm{LPS}$ treatment; lane 5 , direct treatment with $40 \mu \mathrm{g} \mathrm{mL} \mathrm{mWCNTs}^{-1} \mathrm{MOOH}$. Lane 6 , direct treatment with $1 \mu \mathrm{g} \mathrm{mL} \mathrm{L}^{-1}$ LPS. (C) The content of MMP-3 secreted by SW-982 cells in response to the culture medium from MWCNT-treated THP- 1 cells at 20 and $40 \mu \mathrm{g} \mathrm{mL}^{-1}(n=6)$. The MMP-3 content was measured through ELISA.

resulting in cartilage destruction and bone erosion. ${ }^{69,91}$ To this end, we also evaluated the expression of these genes in human chondrocytes, SW-1353 cells. ${ }^{92}$ Similar to the results in synovial cells, the expressions of COX-1 and MMP-1, 2 and -3 were greatly enhanced in SW-1353 cells following incubation with culture medium from MWCNT-treated THP-1 cells, compared to that in SW-1353 cells following incubation with culture medium from THP-1 cells without MWCNT treatment (Fig. 9A-D, $P<0.05$ ). These data thus demonstrated that MWCNT-COOH-induced inflammation also switched the status of chondrocytes from "resting" to activation, leading to their enhanced capacity to secrete factors for matrix degradation.

\section{Blockade of pro-inflammatory cytokines diminished synovial} activation

To substantiate the mechanism underlying MWCNT-induced pro-inflammatory cytokines in activating synoviocytes from a relatively resting state to a highly active state, we further investigated synoviocytes through neutralization experiments. Previous studied have documented a crucial role of TNF- $\alpha$ and IL-1 $\beta$ in the initiation and perpetuation of most forms of 

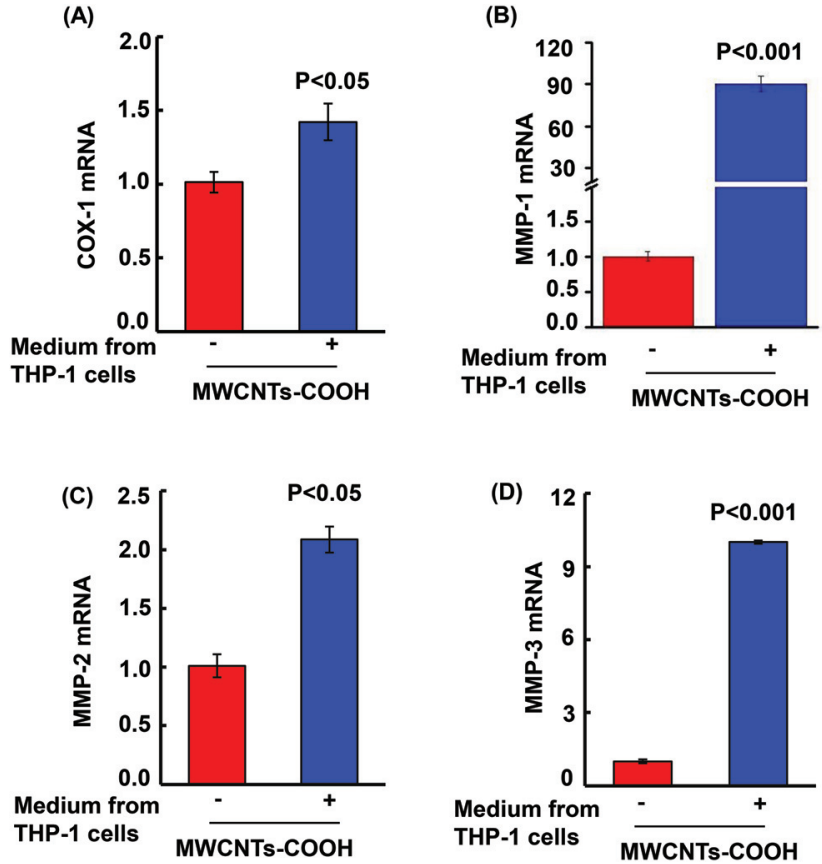

Fig. 9 Activation of chondrocytes by MWCNTs. The expressions of COX-1 (A), MMP-1 (B), MMP-2 (C) and MMP-3 (D) in SW-1353 chondrocytes following incubation with the culture medium from MWCNTtreated THP-1 cells (at $40 \mu \mathrm{g} \mathrm{mL}^{-1}$ ) for $24 \mathrm{~h}(n=6)$.

arthritides, ${ }^{21,37}$ which facilitated synovial cellular infiltration, activation of macrophages, osteoclast and chondrocytes, and also angiogenesis. ${ }^{22,92}$ We herein aimed to identify the intermediate (namely the messenger) between macrophages and synoviocytes. Thus, neutralizing the cytokines secreted from macrophages would be the most desirable method to recognize the effects of these cytokines on synoviocytes. Apart from TNF- $\alpha$ and IL-1 $\beta$ (Fig. 5F and G), we also screened the production of other cytokines. However, other cytokines including IL-17 and IFN- $\gamma$ were not detectable in THP-1 cells upon MWCNT treatment. Therefore, TNF- $\alpha$ and IL- $1 \beta$ were accordingly neutralized in culture medium from MWCNT-treated THP-1 cells with Abs against each, respectively. As shown in Fig. 10, the expressions of MMP-1, MMP-2, MMP-3, MMP-9, COX-1 and COX-2 were diminished in SW-982 synoviocytes following incubation with culture medium from MWCNT-treated THP-1 cells upon neutralization with a TNF- $\alpha$ Ab, with the reduction approximately ranging from $15 \%$ to $60 \%$, relative to the normal IgG control $(P<0.05)$. Similar to the results of TNF- $\alpha$ neutralization, the expression of these genes also significantly declined in SW-982 synoviocytes following incubation with the medium from MWCNT-treated THP-1 cells in response to IL-1 $\beta$ neutralization, compared to the normal IgG control $(P<0.05)$. Based on the current data (Fig. 10), the antiTNF- $\alpha$ Ab diminished MMPs to a greater extent than the antiIL-1 $\beta \mathrm{Ab}$, and the anti-IL-1 $\beta \mathrm{Ab}$ conversely repressed COXs to a greater extent than the anti-TNF- $\alpha \mathrm{Ab}$. However, it should be noted that different Abs (even from different batches) may show variable capabilities in neutralizing their cytokines.

\begin{tabular}{|c|c|c|c|c|}
\hline \multirow{2}{*}{$\begin{array}{l}\text { Target } \\
\text { Genes } \\
\text { MMP-1 }\end{array}$} & \multicolumn{2}{|c|}{$\begin{array}{c}\text { Anti-TNF- } \alpha \text { Ab } \\
\text { (Related to IgG control) }\end{array}$} & \multicolumn{2}{|c|}{$\begin{array}{c}\text { Anti-IL-1 } \beta \text { Ab } \\
\text { (Related to IgG control) }\end{array}$} \\
\hline & $\downarrow \downarrow \downarrow \downarrow$ & $\#$ & $\downarrow$ & $*$ \\
\hline MMP-2 & $\downarrow \downarrow \downarrow \downarrow$ & $\#$ & $\downarrow \downarrow$ & * \\
\hline MMP-3 & $\downarrow \downarrow \downarrow \downarrow \downarrow \downarrow$ & $\#$ & $\downarrow \downarrow \downarrow \downarrow \downarrow$ & $\#$ \\
\hline MMP-9 & $\downarrow \downarrow \downarrow$ & $*$ & $\downarrow \downarrow \downarrow$ & $*$ \\
\hline coX-1 & $\downarrow t$ & * & $\downarrow \downarrow t$ & $*$ \\
\hline coX-2 & $\downarrow$ & * & 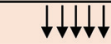 & $\#$ \\
\hline
\end{tabular}

Fig. 10 The relative expression of MMPs and COXs in SW982 cells in response to culture medium from MWCNT-treated THP-1 cells containing selective Ab or normal IgG for $24 \mathrm{~h}(n=6)$. The asterisk (*) indicates $P<0.05$, and the pound sign (\#) denotes $P<0.001$, compared to those in cells following incubation with culture medium from MWCNT-treated THP-1 cells containing normal lgG.

Thus, it would be difficult to compare their exact efficacy in neutralizing their antigens. Nonetheless, these results collectively demonstrated that the production of inflammatory cytokines prominently accounted for synovial cell activation under CNT exposure, and blockade of these cytokines could greatly reverse synovial cell activation.

Primary toxicity is the direct harm induced by an invading toxin, whereas secondary toxicity is the detrimental effects caused by the mediators that are generated due to the presence of the original toxin in the body. For example, the primary toxicity of asbestos is the inflammation due to the presence of asbestos fibers. Meanwhile, the secondary toxicity of asbestos is pathological changes induced as a result of inflammatory conditions and pro-inflammatory cytokines. ${ }^{96,97}$ Many studies have centered on the direct toxicities of CNTs to the direct target tissues and organs, while few studies centered on the secondary and compensatory effects beyond primary targets. ${ }^{98}$ From this perspective, many reports have described the proinflammatory effects of MWCNTs with various in vitro or in vivo models; ${ }^{99,100}$ however, little is known about their secondary toxicity under CNT-stimulated pro-inflammatory conditions. In the current study, we reported a novel finding on the secondary toxicity induced by CNTs: synovial inflammation due to systemic pro-inflammatory responses. Inflammatory responses within knee joints (as evidenced by the infiltration of leukocytes and synovial hyperplasia) is an early phenotype for most forms of arthritis. ${ }^{23,101}$ Under the normal conditions, chondrocytes are maintained in a stable equilibrium between the synthesis and degradation of matrix components. Under pathological conditions, pro-inflammatory cytokines play a vital role in altering the state of immune cells, synoviocytes and chondrocytes. ${ }^{2,101}$ As a result, inflammatory cells, synoviocytes and chondrocytes themselves are activated to secrete diverse substances to enhance cartilage destruction and bone erosion. ${ }^{22,102}$ Increased concentrations of these cytokines (e.g. IL-1 $\beta$ and TNT- $\alpha$ ) would activate synoviocytes and chondrocytes to enhance MMP production, resulting in cartilage destruction. In the current study, we demonstrated that MWCNTs$\mathrm{COOH}$ significantly changed the priming status of synoviocytes and chondrocytes through provoking pro-inflammatory reac- 
tions, leading to enforced production and activity of MMP and COX members that are necessary for the progressive destruction of cartilage. Therefore, our study highlights the importance of understanding the secondary toxicity as a result of MWCNT-induced systemic inflammation.

\section{Conclusions}

Although a huge number of studies have investigated the toxicity of MWCNTs, most focused on the direct effects on target organs, tissue or cells. ${ }^{99,103,104}$ In the current study, we explored the secondary effects of MWCNT exposure on knee joints. We found that MWCNT exposure could generate systemic inflammation, which changed the priming state of synoviocytes and chondrocytes, as evidenced by enhanced production and activity of joint degeneration related molecules including MMP-1, -2 and -3 and COX-1, and -2. In vivo exposure of MWCNTs caused significant arthritis syndromes, including synovial inflammation and articular degeneration within knees in mice. In addition to the oxidative stress, fibrosis, autophagy and lysosome damage reported in the literature, ${ }^{25,38,76}$ we further showed that CNT-induced systemic proinflammatory cytokines could induce synovial inflammation by interfering in the priming state of synoviocytes and chondrocytes. Therefore, our findings provide a novel perspective to understand the toxicological features of MWCNTs, especially their secondary toxicity in remote sites.

\section{Competing interests}

There is no potential conflict of interests to disclose.

\section{Acknowledgements}

This work was supported by a grant under the national "973" programme (grant number 2014CB932000), the Strategic Priority Research Program of the Chinese Academy of Sciences (grant no. XDB14000000) and grants from the National Natural Science Foundation of China (grant numbers 21425731, 21077128, 81373039, 91543124 and 21637004). This work was also supported by One Hundred Talents (Bairen A) program of Chinese Academy of Sciences (TX) and the New Century National Millions of Talents Project (YL).

\section{References}

1 A. Di Crescenzo, D. Velluto, J. A. Hubbell and A. Fontana, Nanoscale, 2011, 3(3), 925-928.

2 L. Chang, J. Hu, F. Chen, Z. Chen, J. Shi, Z. Yang, Y. Li and L. J. Lee, Nanoscale, 2016, 8(6), 3181-3206.

3 L. Zhang, P. Rong, M. Chen, S. Gao and L. Zhu, Nanoscale, 2015, 7(39), 16204-16213.
4 Z. Yang, S. G. Kang and R. Zhou, Nanoscale, 2014, 6(2), 663-677.

5 C. Farrera, K. Bhattacharya, B. Lazzaretto, F. T. Andon, K. Hultenby, G. P. Kotchey, A. Star and B. Fadeel, Nanoscale, 2014, 6(12), 6974-6983.

6 L.-C. Cheng, X. Jiang, J. Wang, C. Chen and R.-S. Liu, Nanoscale, 2013, 5(9), 3547.

7 J. Y. Hwang, U. S. Shin, W. C. Jang, J. K. Hyun, I. B. Wall and H. W. Kim, Nanoscale, 2013, 5(2), 487-497.

8 J. Dong and Q. Ma, Nanotoxicology, 2015, 9(5), 658676.

9 M. Zhang, M. Yang, C. Bussy, S. Iijima, K. Kostarelos and M. Yudasaka, Nanoscale, 2015, 7(7), 2834-2840.

10 A. Pietroiusti, Nanoscale, 2012, 4(4), 1231-1247.

11 M. Turabekova, B. Rasulev, M. Theodore, J. Jackman, D. Leszczynska and J. Leszczynski, Nanoscale, 2014, 6(7), 3488-3495.

12 G. T. Ankley, R. S. Bennett, R. J. Erickson, D. J. Hoff, M. W. Hornung, R. D. Johnson, D. R. Mount, J. W. Nichols, C. L. Russom, P. K. Schmieder, J. A. Serrrano, J. E. Tietge and D. L. Villeneuve, Environ. Toxicol. Chem., 2010, 29(3), 730-741.

13 G. T. Ankley, R. S. Bennett, R. J. Erickson, D. J. Hoff, M. W. Hornung, R. D. Johnson, D. R. Mount, J. W. Nichols, C. L. Russom, P. K. Schmieder, J. A. Serrrano, J. E. Tietge and D. L. Villeneuve, Environ. Toxicol. Chem./SETAC, 2010, 29(3), 730-741.

14 J. P. Ryman-Rasmussen, M. F. Cesta, A. R. Brody, J. K. Shipley-Phillips, J. I. Everitt, E. W. Tewksbury, O. R. Moss, B. A. Wong, D. E. Dodd, M. E. Andersen and J. C. Bonner, Nat. Nanotechnol., 2009, 4(11), 747-751.

15 Y. Zhao, Q. Wu, Y. Li, A. Nouara, R. Jia and D. Wang, Nanoscale, 2014, 6(8), 4275-4284.

16 P. Jackson, K. S. Hougaard, U. Vogel, D. Wu, L. Casavant, A. Williams, M. Wade, C. L. Yauk, H. Wallin and S. Halappanavar, Mutat. Res., 2012, 745(1-2), 73-83.

17 Y. Bai, Y. Zhang, J. Zhang, Q. Mu, W. Zhang, E. R. Butch, S. E. Snyder and B. Yan, Nat. Nanotechnol., 2010, 5(9), 683-689.

18 C. Qu, L. Wang, J. He, J. Tan, W. Liu, S. Zhang, C. Zhang, Z. Wang, S. Jiao, S. Liu and G. Jiang, Gene, 2012, 493(1), 9-12.

19 M. E. Kotas and R. Medzhitov, Cell, 2015, 160(5), 816-827.

20 M. S. Chimenti, P. Triggianese, P. Conigliaro, E. Candi, G. Melino and R. Perricone, Cell Death Dis., 2015, 6, e1887.

21 M. Kapoor, J. Martel-Pelletier, D. Lajeunesse, J.-P. Pelletier and H. Fahmi, Nat. Rev. Rheumatol., 2011, 7(1), 33-42.

22 I. B. McInnes and G. Schett, Nat. Rev. Immunol., 2007, 7(6), 429-442.

23 E. Choy, Rheumatology, 2012, 51(suppl 5), v3-v11.

24 N. A. Pascarelli, E. Moretti, G. Terzuoli, A. Lamboglia, T. Renieri, A. Fioravanti and G. Collodel, J. Appl. Toxicol., 2013, 33(12), 1506-1513.

25 R. Li, X. Wang, Z. Ji, B. Sun, H. Zhang, C. H. Chang, S. Lin, H. Meng, Y.-P. Liao, M. Wang, Z. Li, A. Hwang, 
T.-B. Song, R. Xu, Y. Yang, J. I. Zink, A. E. Nel and T. Xia, ACS Nano, 2013, 7(3), 2352-2368.

26 D. D. Chronopoulos, C. G. Kokotos, N. Karousis, G. Kokotos and N. Tagmatarchis, Nanoscale, 2015, 7(6), 2750-2757.

27 J. T. Andersson and C. Achten, Polycyclic Aromat. Compd., 2015, 35(2-4), 330-354.

28 Z. Zelinkova and T. Wenzl, Polycyclic Aromat. Compd., 2015, 35(2-4), 248-284.

29 Q. X. Lv, W. Wang, X. H. Li, L. Yu, Y. Zhang and Y. Tian, Environ. Pollut., 2015, 199, 219-226.

30 S. Li, L. Wang, M. Berman, Y.-Y. Kong and M. E. Dorf, Immunity, 2011, 35(3), 426-440.

31 J. Ma, R. Liu, X. Wang, Q. Liu, Y. Chen, R. P. Valle, Y. Y. Zuo, T. Xia and S. Liu, ACS Nano, 2015, 9(10), 1049810515.

32 J. Vandesompele, K. De Preter, F. Pattyn, B. Poppe, N. Van Roy, A. De Paepe and F. Speleman, Genome Biol., 2002, 3(7), research0034.1-research0034.11.

33 X. Cui, S. Yu, A. Tamhane, Z. L. Causey, A. Steg, M. I. Danila, R. J. Reynolds, J. Wang, K. C. Wanzeck, Q. Tang, S. S. Ledbetter, D. T. Redden, M. R. Johnson and S. L. Bridges, BMC Genomics, 2015, 16(1), 82.

34 V. Zaga-Clavellina, G. Garcia-Lopez, A. Flores-Pliego, H. Merchant-Larios and F. Vadillo-Ortega, Reprod. Biol. Endocrinol., 2011, 9(1), 13.

35 S. Zhang, Y. Chen, W. Guo, L. Yuan, D. Zhang, Y. Xu, E. Nemeth, T. Ganz and S. Liu, Cell. Signalling, 2014, 26(11), 2539-2550.

36 S. Liu, R. N. V. S. Suragani, F. Wang, A. Han, W. Zhao, N. C. Andrews and J.-J. Chen, J. Clin. Invest., 2007, 117(11), 3296-3305.

37 L. Yan, F. Zhao, S. Li, Z. Hu and Y. Zhao, Nanoscale, 2011, 3(2), 362-382.

38 T. X. Xiang Wang, S. A. Ntim, Z. Ji, S. Lin, H. Meng, C.-H. Chung, S. George, H. Zhang, M. Wang, N. Li, Y. Yang, V. Castranova, Z. Somenath Mitra, J. C. Bonner and A. E. Nel, ACS Nano, 2011, 5(12), 9772-9787.

39 X. Wang, T. Xia, M. C. Duch, Z. Ji, H. Zhang, R. Li, B. Sun, S. Lin, H. Meng, Y.-P. Liao, M. Wang, T.-B. Song, Y. Yang, M. C. Hersam and A. E. Nel, Nano Lett., 2012, 12(6), 30503061.

40 X. Wang, T. Xia, S. A. Ntim, Z. Ji, S. George, H. Meng, H. Zhang, V. Castranova, S. Mitra and A. E. Nel, ACS Nano, 2010, 4(12), 7241-7252.

41 B. D. Chithrani and W. C. W. Chan, Nano Lett., 2007, 7(6), 1542-1550.

42 A. Lesniak, F. Fenaroli, M. P. Monopoli, C. Åberg, K. A. Dawson and A. Salvati, ACS Nano, 2012, 6(7), 5845-5857.

43 S. S. J. Aravind, P. Baskar, T. T. Baby, R. K. Sabareesh, S. Das and S. Ramaprabhu, J. Phys. Chem. C, 2011, 115(34), 16737-16744.

44 Z. J. Zhang, P. Cui, C. Chen, X. Y. Chen and J. W. Liu, J. Solid State Electrochem., 2013, 18(1), 59-67.

45 W.-H. Liao, H.-W. Tien, S.-T. Hsiao, S.-M. Li, Y.-S. Wang, Y.-L. Huang, S.-Y. Yang, C.-C. M. Ma and Y.-F. Wu, ACS Appl. Mater. Interfaces, 2013, 5(9), 3975-3982.
46 H.-Z. Geng, K. K. Kim, K. P. So, Y. S. Lee, Y. Chang and Y. H. Lee, J. Am. Chem. Soc., 2007, 129(25), 7758-7759.

47 Y. Zhang, Q. Mu, H. Zhou, K. Vrijens, M. F. Roussel, G. Jiang and B. Yan, Cell Death Dis., 2012, 3(5), e308.

48 N. Gao, Q. Zhang, Q. Mu, Y. Bai, L. Li, H. Zhou, E. R. Butch, T. B. Powell, S. E. Snyder, G. Jiang and B. Yan, ACS Nano, 2011, 5(6), 4581-4591.

49 D. Bohrer, R. Hörner, P. C. c. d. Nascimento, M. Adaime, M. E. Pereira, A. F. Martins and S. A. Hartz, J. Pharm. Biomed. Anal., 2001, 26, 811-818.

50 G. Qu, S. Liu, S. Zhang, L. Wang, X. Wang, B. Sun, N. Yin, X. Gao, T. Xia, J.-J. Chen and G.-B. Jiang, ACS Nano, 2013, $7(7), 5732-5745$.

51 K. Donaldson, F. A. Murphy, R. Duffin and C. A. Poland, Part. Fibre Toxicol., 2010, 7(5), 1-17.

52 L. Rushton, Rev. Environ. Health, 2007, 22(3), 195-212.

53 J. T. W. Wang, N. Rubio, H. Kafa, E. Venturelli, C. Fabbro, C. Ménard-Moyon, T. DaRos, J. K. Sosabowski, A. D. Lawson, M. K. Robinson, M. Prato, A. Bianco, F. Festy, J. E. Preston, K. Kostarelos and K. T. Al-Jamal, J. Controlled Release, 2016, 224, 22-32.

54 M. R. McDevitt, D. Chattopadhyay, J. S. Jaggi, R. D. Finn, P. B. Zanzonico, C. Villa, D. Rey, J. Mendenhall, C. A. Batt, J. T. Njardarson and D. A. Scheinberg, PLoS One, 2007, 2(9), e907.

55 R. Singh, D. Pantarotto, L. Lacerda, G. Pastorin, C. Klumpp, M. Prato, A. Bianco and K. Kostarelos, Proc. Natl. Acad. Sci. U. S. A., 2006, 103(9), 3357-3362.

56 M. Roldo and D. G. Fatouros, Annu. Rep. Prog. Chem., Sect. C: Phys. Chem., 2013, 109, 10-35.

57 V. Biju, Chem. Soc. Rev., 2014, 43(3), 744-764.

58 Z. Liu, K. Chen, C. Davis, S. Sherlock, Q. Cao, X. Chen and H. Dai, Cancer Res., 2008, 68(16), 6652-6660.

59 L. Ruibin, W. Ren'an, Z. Liang, Q. Hongqiang, W. Jianlin, Z. Jingwen, B. Ruyi and Z. Hanfa, Nanotechnology, 2014, 25(49), 495102.

60 S. H. De Paoli, L. L. Diduch, T. Z. Tegegn, M. Orecna, M. B. Strader, E. Karnaukhova, J. E. Bonevich, K. Holada and J. Simak, Biomaterials, 2014, 35(24), 6182-6194.

61 G. Tarantino, S. Savastano, D. Capone and A. Colao, World J. Gastroenterol., 2011, 17(33), 3776-3784.

62 L. G. Delogu, G. Vidili, E. Venturelli, C. Ménard-Moyon, M. A. Zoroddu, G. Pilo, P. Nicolussi, C. Ligios, D. Bedognetti, F. Sgarrella, R. Manetti and A. Bianco, Proc. Natl. Acad. Sci. U. S. A., 2012, 109(41), 16612-16617.

63 A. Albini, A. Pagani, L. Pulze, A. Bruno, E. Principi, T. Congiu, E. Gini, A. Grimaldi, B. Bassani, S. De Flora, M. de Eguileor and D. M. Noonan, Int. J. Nanomed., 2015, 10, 6133-6145.

64 A. Al Faraj, K. Cieslar, G. Lacroix, S. Gaillard, E. CanetSoulas and Y. Crémillieux, Nano Lett., 2009, 9(3), 10231027.

65 A. Nel, Science, 2006, 311(5761), 622-627.

66 L. Lacerda, H. Ali-Boucetta, S. Kraszewski, M. Tarek, M. Prato, C. Ramseyer, K. Kostarelos and A. Bianco, Nanoscale, 2013, 5(21), 10242-10250. 
67 M. Otero and M. B. Goldring, Arthritis Res. Ther., 2007, 9(5), 220.

68 G. S. Firestein, Nature, 2003, 423, 356-361.

69 L. Troeberg and H. Nagase, Biochim. Biophys. Acta, 2012, 1824(1), 133-145.

70 J. S. Rockel and M. Kapoor, Nat. Rev. Rheumatol., 2016, DOI: 10.1038/nrrheum.2016.166.

71 S. P. Grogan and D. D. D'Lima, Int. J. Clin. Rheumtol., 2010, 5(2), 199-214.

72 M. B. Maeß, B. Wittig, A. Cignarella and S. Lorkowski, J. Immunol. Methods, 2013, 76-81.

73 N. Li, T. Xia and A. E. Nel, Free Radicals Biol. Med., 2008, 44(9), 1689-1699.

74 A. Nel, T. Xia, L. Mädler and N. Li, Science, 2006, 311, 622627.

75 F. Martinon, Eur. J. Immunol., 2010, 40(3), 616-619.

76 J. Palomäki, E. Välimäki, J. Sund, M. Vippola, P. A. Clausen, K. A. Jensen, K. Savolainen, S. Matikainen and H. Alenius, ACS Nano, 2011, 5(9), 6861-6870.

77 M. T. Sorbara and S. E. Girardin, Cell Res., 2011, 21(4), 558-560.

78 K. A. Shipkowski, A. J. Taylor, E. A. Thompson, E. E. Glista-Baker, B. C. Sayers, Z. J. Messenger, R. N. Bauer, I. Jaspers and J. C. Bonner, PLoS One, 2015, 10(6), e0128888.

79 X. He, S.-H. Young, D. Schwegler-Berry, W. P. Chisholm, J. E. Fernback and Q. Ma, Chem. Res. Toxicol., 2011, 24(12), 2237-2248.

80 O. Takeuchi and S. Akira, Cell, 2010, 140(6), 805-820.

81 T. Osamu and A. Shizuo, Cell, 2010, 140(6), 805-820.

82 T. Kawai and S. Z. Akira, Int. Immunol., 2009, 21(4), 317337.

83 T. Kawai and S. Akira, Int. Immunol., 2009, 21(4), 317-337.

84 M. Guha and N. Mackman, Cell. Signalling, 2001, 13, 8594.

85 S. S. Mano, K. Kanehira and A. Taniguchi, Int. J. Mol. Sci., 2013, 14(7), 13154-13170.

86 M. Akutsu, N. Ogura, K. Ito, M. Kawashima, T. Kishida and T. Kondoh, J. Oral Pathol. Med., 2013, 42(6), 491-498.

87 C. Pasare and R. Medzhitov, Microbes Infect., 2004, 6(15), 1382-1387.

88 J. S. Kim, K. D. Kim, H. S. Na, S. Y. Jeong, H. R. Park, S. Kim and J. Chung, Mol. Oral Microbiol., 2012, 27(3), 149-159.
89 E. M. Choi and Y. S. Lee, Food Chem. Toxicol., 2010, 48(10), 2607-2611.

90 J. C. Rousseau and P. D. Delmas, Nat. Clin. Pract. Rheumatol., 2007, 3(6), 346-356.

91 S. B. Abramson, Osteoarthritis and Cartilage, 1999, 7(4), 380-381.

92 Y.-C. Lu, T. Jayakumar, Y.-F. Duann, Y.-C. Chou, C.-Y. Hsieh, S.-Y. Yu, J.-R. Sheu and G. Hsiao, J. Agric. Food Chem., 2011, 59(9), 4969-4978.

93 K. Briknarova, M. Gehrmann, L. Banyai, H. Tordai, L. Patthy and M. Llinas, J. Biol. Chem., 2001, 276(29), 27613-27621.

94 I. E. Collier, S. M. Wilhelm, A. Z. Eisen, B. L. Marmer, G. A. Grant, Jo L. Seltzer, h. H. Annemarie KronbergerC, E. A. Bauer and G. Goldberg, J. Biol. Chem., 1988, 263(14), 6579-6587.

95 Y. Zhao, F. L. Zhou, W. P. Li, J. Wang and L. J. Wang, Mol. Med. Rep., 2016, 1901-1906.

96 G. Tweedale, Nat. Rev. Cancer, 2002, 2(4), 311-314.

97 G. Boulanger, P. Andujar, J.-C. Pairon, M.-A. BillonGalland, C. Dion, P. Dumortier, P. Brochard, A. Sobaszek, P. Bartsch, C. Paris and M.-C. Jaurand, Environ. Health, 2014, 13, 59-59.

98 S. S. Poulsen, A. T. Saber, A. Mortensen, J. Szarek, D. Wu, A. Williams, O. Andersen, N. R. Jacobsen, C. L. Yauk, H. Wallin, S. Halappanavar and U. Vogel, Toxicol. Appl. Pharmacol., 2015, 283(3), 210-222.

99 C. A. Poland, R. Duffin, I. Kinloch, A. Maynard, W. A. H. Wallace, A. Seaton, V. Stone, S. Brown, W. MacNee and K. Donaldson, Nat. Nanotechnol., 2008, 3(7), 423-428.

100 C. Crescio, M. Orecchioni, C. Menard-Moyon, F. Sgarrella, P. Pippia, R. Manetti, A. Bianco and L. G. Delogu, Nanoscale, 2014, 6(16), 9599-9603.

101 S. Umar, A. H. M. Golam Sarwar, K. Umar, N. Ahmad, M. Sajad, S. Ahmad, C. K. Katiyar and H. A. Khan, Cell. Immunol., 2013, 284(1-2), 51-59.

102 F. M. Brennan and I. B. McInnes, J. Clin. Invest., 2008, 118(11), 3537-3545.

103 S. L. Yoong, W. L. Lau, A. Y. Liu, D. Prendergast, H. K. Ho, V. C. Yu, C. Lee, W. H. Ang and G. Pastorin, Nanoscale, 2015, 7(33), 13907-13917.

104 C. Bussy, C. Hadad, M. Prato, A. Bianco and K. Kostarelos, Nanoscale, 2015, 8(1), 590-601. 